\title{
The Last Ten Years of Advancements in Plant-Derived Recombinant Vaccines against Hepatitis B
}

\author{
Young Hee Joung ${ }^{1}$, Se Hee Park ${ }^{1}$, Ki-Beom Moon ${ }^{2}$, Jae-Heung Jeon ${ }^{2}$, Hye-Sun Cho ${ }^{2}$ and \\ Hyun-Soon Kim ${ }^{2, *}$ \\ 1 School of Biological Sciences \& Technology, Chonnam National University, Gwangju 61186, Korea; \\ yhjoung@chonnam.ac.kr (Y.H.J.); shpark860@daum.net (S.H.P.) \\ 2 Molecular Biofarming Research Center, Korea Research Institute of Bioscience \& Biotechnology (KRIBB), \\ Daejeon 34141, Korea; irony83@kribb.re.kr (K.-B.M.); jeonjh@kribb.re.kr (J.-H.J.); hscho@kribb.re.kr (H.-S.C.) \\ * Correspondence: hyuns@kribb.re.kr; Tel.: +82-42-860-4493; Fax: +82-42-860-4599
}

Academic Editor: Chang Won Choi

Received: 26 August 2016; Accepted: 29 September 2016; Published: 13 October 2016

\begin{abstract}
Disease prevention through vaccination is considered to be the greatest contribution to public health over the past century. Every year more than 100 million children are vaccinated with the standard World Health Organization (WHO)-recommended vaccines including hepatitis B (HepB). HepB is the most serious type of liver infection caused by the hepatitis B virus (HBV), however, it can be prevented by currently available recombinant vaccine, which has an excellent record of safety and effectiveness. To date, recombinant vaccines are produced in many systems of bacteria, yeast, insect, and mammalian and plant cells. Among these platforms, the use of plant cells has received considerable attention in terms of intrinsic safety, scalability, and appropriate modification of target proteins. Research groups worldwide have attempted to develop more efficacious plant-derived vaccines for over 30 diseases, most frequently HepB and influenza. More inspiring, approximately 12 plant-made antigens have already been tested in clinical trials, with successful outcomes. In this study, the latest information from the last 10 years on plant-derived antigens, especially hepatitis B surface antigen, approaches are reviewed and breakthroughs regarding the weak points are also discussed.
\end{abstract}

Keywords: antigen; hepatitis B virus; plant edible vaccine; recombinant protein; molecular farming; virus-like particles

\section{Introduction}

Hepatitis B (HepB) is an infection with the hepatitis B virus (HBV), which attacks the liver and can cause both acute and chronic disease. The World Health Organization (WHO) estimates that 240 million persons are chronically infected with HBV and that more than 780,000 people die every year due to complications of $\mathrm{HepB}$, including cirrhosis and liver cancer [1]. The point that needs the most attention is the high rates of chronic infection found in the sub-Saharan Africa and East Asia, where between $5 \%$ and $10 \%$ of the adult population is infected, as well as in the Amazon and the southern parts of eastern and central Europe. Otherwise, less than 1\% of the population in Western Europe and North America is chronically infected [1].

HBV is a hepatotropic DNA virus that replicates by reverse transcription. The human HBV is a small circular DNA molecule of $3.2 \mathrm{~kb}$ [2]. Its genome consists of four partially overlapping open reading frames (ORFs), namely the envelope gene (pre-surface/surface (pre-S/S)), the core gene (pre-core/core $($ pre-C/C)), the polymerase gene $(\mathrm{pol})$ and the transactivating protein $\mathrm{X}(\mathrm{X})$. The ORF pre-S/S encodes pre-S1, pre-S2 and surface (S) proteins that form the surface antigen (HBsAg), and HBsAg protein is the main antigen to elicit virus-neutralizing and protective antibodies by 
the immune system $[3,4]$. Understanding the HBV genome and structure is an essential prerequisite for preventive or therapeutic vaccination against HepB.

\section{Approach for HBV Vaccine}

A vaccine against HepB has been available since 1982. This first licensed anti-HBV vaccine containing subviral particles of HBV purified from the inactivated serum of carriers revealed very high efficacy [5], and a subsequent subunit vaccine made using the small surface antigen (S-HBsAg) was developed in the early 1980s [6]. The yeast system for the recombinant antigen was to ensure safety and low cost. Yeast-derived S-HBsAg assembled into virus-like particles (VLPs) were as immunogenic as natural subviral particles, and highly effective vaccines containing S-HBsAg have been widely used as prophylactic vaccines against HBV infection [7]. However, some groups of vaccines do not develop protective immunity against the virus and immunosenescence frequently occurs in adults [8]. Additionally, high cost limit and the necessity of accompanying infrastructure for the cold chain distribution and intravenous administration still constituted a barrier to vaccination approaches in developing countries. In order to successfully solve these problems, many research projects have been undertaken to develop more efficacious, easily administrated, and thermostable vaccines.

A new recombinant $\mathrm{HBV}$ vaccine containing the pre-S/S has greater immunogenic potential than the conventional $S$ antigen-based vaccines in terms of antibody induction and cellular immune response. Middle (pre-S2 + S, M-HBsAg) or large (pre-S1 + pre-S2 + S, L-HBsAg) surface antigens [9] have been used as components of specific immunotherapeutic vaccines for chronic HBV carriers [10,11]. Additionally, chimeric protein created by fusing the HBV core antigen (HBcAg) to the pre-S1 showed strong anti-HBc and moderate anti-pre-S1 immune responses [12].

\section{Plant-Based Expression System for Vaccine Development}

Although vaccination is one of the most powerful and cost-competitive achievements, some vaccines may still have certain limitations related to maintenance of the cold chain, downstream processing costs, administration risk, and expensive scalability [13-17]. From these reasons, the use of plant cells as alternative production platforms have received considerable attention in terms of intrinsic safety, scalability, and posttranslational modification of target proteins $[17,18]$. Plant systems can be scaled up quickly to generate large quantities of the protein product, are not susceptible to contamination with known human or mammalian pathogens and are resistant to enzymatic digestion in the gastrointestinal tract. In addition, transgenic plants can be engineered to express and translate multiple proteins concurrently with appropriate folding and assembly into multimeric proteins, especially the posttranslational adjustments of antibodies. Not all recombinant antigens will benefit from plant-based systems, but the best production system for each recombinant protein should be chosen using a case-by-case approach [19]. Merlin et al. [19] proposed that plants are the most the beneficial for the production of four major categories of pharmaceutical proteins: ones that are required in large quantities, that need to be rapid-response, that require complex posttranslational modifications, or that are intended for oral delivery. Within these categories, they suggested appropriate candidates to meet a spectrum of research, development, commercial needs, such as human glutamic acid decarboxylase, Norwalk virus-like particles, monoclonal antibody 2G12, and human interleukin-6.

Those plant-made antigens have already been tested in clinical trials, with successful outcomes (Table 1). The enzyme glucocerebrosidase for Gaucher's disease, the first PMF-derived enzyme "ELELYSO ${ }^{\mathrm{TM}}$ ", has been approved and marketed by Protalix in 2012. ELELYSO ${ }^{\mathrm{TM}}$ is based on the use of carrot cells to produce recombinant taliglucerase alpha, which is used in enzyme replacement therapy to treat adult patients. This special Food and Drug Administration (FDA) approval case was fast tracked based on its applicability to a rare genetic disease and the bioreactor production under stringent conditions [20,21]. Medicago has ongoing phase II clinical trials for a plant-derived VLP quadrivalent seasonal influenza vaccine and an $\mathrm{H} 5$ pandemic influenza vaccine [22]. They are focusing on VLP vaccine development. VLPs are self-assembled structures derived from viral antigens 
that mimic the native architecture of viruses but lack the viral genome and thus are not infective. Another important advantage as emerging vaccine is the more effective activation of key aspects of the immune response to achieve potent immune stimulation and to provide immunological memory for long-lasting protection [22,23]. Several reports on the expression of properly assembled VLPs at adequate levels have been published for the influenza virus [24], human papillomavirus [25], human immunodeficiency virus [26,27], Norwalk virus [28], and hepatitis B virus [26,29,30]. In recent, VLPs have been applied in various fields, not only as vaccines [31,32] but also as delivery agents for therapeutic medicine [33-36]. In addition, Paul et al. [37] summarized four major developments of molecular pharmaceuticals occurring in the world. More recently, Yao et al. [21] reviewed the challenges and opportunities of plant molecular farming, including various examples of clinical trials from the perspectives of biosafety, appropriate expression systems, and possible and potential application.

Plant-based platforms including whole plant, organs or cell and expression technology to produce target antigens of interest are diverse [38-40]. Representative plant species expressing the oral vaccine are potato, tomato, and tobacco; additionally, maize, rice, carrot, and soybean are also applied in this field [41-49]. Those plants are mainly focused on traditional and usually eaten crops in human, because it is known that inexperienced plants sometimes have problems with certain plant allergies. Target antigen proteins were expressed by a plant cell nuclear genome expression system in these plant species. Edible plant vaccines are based on different parts of plants, such as fruits, seeds, and root vegetables. Such food vaccines are prepared directly without expensive purification of the antigens, which is essentially required for parenteral administration of vaccines [50]. Therefore, the lyophilization of organs expressing stable antigens would facilitate their processing, purification and storage, reducing costs and allowing more practical vaccines. Although stable transformation into transgenic plants is commonly accepted, the low production level of the resultant recombinant protein remains an issue of concern. An efficient alternative to nuclear transformation for vaccine antigens and other therapeutic proteins is plastid transformation [51]. The highest expression of transgenes, up to more than $70 \%$ of total soluble protein, are reported in chloroplast transformation $[52,53]$ Otherwise, the universal expression level in most studies has been $1 \%$ of total soluble protein (TSP) or $50 \mu \mathrm{g} / \mathrm{g}$ fresh leaf tissue [54,55]. Chloroplast technology can also avoid the controversy related to transgene containment [40] and express multigenes as single operon [56]. Waheed et al. [40] reviewed recent vaccine antigens against human diseases expressed via plastid genome since 2011. Two plant species, tobacco (15 different antigens) and lettuce (four different antigens), have mainly been used in plastid transformation. These results suggest that more industrial interest is needed to strengthen the research/academia-industry linkages in the chloroplast-based vaccine market.

Stable transformation has its own advantages such as reliable harvest of target proteins over multiple generations and optimized protocols for delivery of foreign genes into various plant species. Although there are problems with the time required, seed resources can be grown anywhere with minimal cost and labor once the plant has been developed for the first time [21]. 
Table 1. Clinical studies of plant-derived vaccines (data from US National Institutes of Health clinical trial).

\begin{tabular}{|c|c|c|c|}
\hline Application & Study & Status & Sponsor \\
\hline Anthrax (1) & $\begin{array}{l}\text { A Phase I Study of the Safety and Immunogenicity of Plant-Derived } \\
\text { Recombinant Protective Antigen (rPA) Anthrax Vaccine in Healthy Adults }\end{array}$ & $\begin{array}{l}\text { Phase I (2015), } \\
\text { ongoing (NCT02239172) }\end{array}$ & $\begin{array}{l}\text { Fraunhofer, Center for } \\
\text { Molecular Biotechnology }\end{array}$ \\
\hline \multirow{3}{*}{ Influenza, Human (3) } & Safety and Immunogenicity of a Recombinant H5N1 Vaccine in Adults & Unknown (2011), (NCT01250795) & $\begin{array}{l}\text { Fraunhofer, Center for } \\
\text { Molecular Biotechnology }\end{array}$ \\
\hline & $\begin{array}{l}\text { Immunogenicity, Safety and Tolerability of a Plant-Derived Seasonal } \\
\text { Virus-Like-Particle Quadrivalent Influenza Vaccine in Adults }\end{array}$ & $\begin{array}{l}\text { Phase II (2015), } \\
\text { ongoing (NCT02233816) }\end{array}$ & Medicago \\
\hline & $\begin{array}{l}\text { Immunogenicity, Safety and Tolerability of a Plant-Derived Seasonal VLP } \\
\text { Quadrivalent Influenza Vaccine in the Elderly Population }\end{array}$ & $\begin{array}{l}\text { Phase II (2015), } \\
\text { ongoing (NCT02236052) }\end{array}$ & Medicago \\
\hline Malaria & $\begin{array}{l}\text { Safety and Immunogenicity of Plant-Derived Pfs } 25 \text { VLP-FhCMB Malaria } \\
\text { Transmission Blocking Vaccine in Healthy Adults }\end{array}$ & $\begin{array}{l}\text { Phase I (2015), } \\
\text { ongoing (NCT02013687) }\end{array}$ & $\begin{array}{l}\text { Fraunhofer, Center for } \\
\text { Molecular Biotechnology }\end{array}$ \\
\hline Gaucher Disease & $\begin{array}{l}\text { A Phase III Trial to Assess the Safety and Efficacy of Plant Cell Expressed } \\
\text { GCD in Patients With Gaucher Disease }\end{array}$ & $\begin{array}{l}\text { Phases III, } \\
\text { completed (2012) (NCT00376168) }\end{array}$ & Protalix \\
\hline Ebola Virus & $\begin{array}{l}\text { Putative Investigational Therapeutics in the Treatment of Patients With } \\
\text { Known Ebola Infection }\end{array}$ & $\begin{array}{l}\text { Phase I,II, } \\
\text { recruiting (2015) (NCT02363322) }\end{array}$ & $\begin{array}{l}\text { Zmapp, National Institute } \\
\text { of Allergy and Infectious } \\
\text { Diseases (NIAID) }\end{array}$ \\
\hline Fabry disease & $\begin{array}{l}\text { An Extension of a Phase I/II, Open Label, Dose Ranging Study of PRX-102 } \\
\text { in Adult Fabry Patients }\end{array}$ & $\begin{array}{l}\text { Phase I,II, } \\
\text { enrolling (2015) (NCT01769001) }\end{array}$ & Protalix \\
\hline $\begin{array}{l}\text { Human } \\
\text { Immunodeficiency Virus }\end{array}$ & $\begin{array}{l}\text { A Safety Study Of A Single Vaginal Administration of P2G12 Antibody In } \\
\text { Healthy Female Subjects }\end{array}$ & $\begin{array}{l}\text { Phase I, } \\
\text { completed (NCT01403792) }\end{array}$ & $\begin{array}{l}\text { University of Surrey } \\
\text { (European Commission) }\end{array}$ \\
\hline $\begin{array}{l}\text { Influenza A Subtype } \\
\text { H5N1 Infection }\end{array}$ & H5-VLP + GLA-AF Vaccine Trial in Healthy Adult Volunteers & $\begin{array}{l}\text { Phase I, } \\
\text { completed (NCT01657929) }\end{array}$ & $\begin{array}{l}\text { Infectious Disease Research } \\
\text { Institute (IDRI), Medicago }\end{array}$ \\
\hline Vitamin B12 Deficiency & $\begin{array}{l}\text { Can Recombinant Human Intrinsic Factor Be Used for Evaluation of the } \\
\text { Vitamin B12 Absorption? }\end{array}$ & $\begin{array}{l}\text { Phase II, } \\
\text { completed (NCT00279552) }\end{array}$ & University of Aarhus \\
\hline Healthy & Safety and Immunogenicity of a Recombinant H5N1 Vaccine in Adults & $\begin{array}{l}\text { Phase I, } \\
\text { unknown (NCT01250795) }\end{array}$ & $\begin{array}{l}\text { Fraunhofer, Center for } \\
\text { Molecular Biotechnology }\end{array}$ \\
\hline
\end{tabular}


Most clinical trials, except for the three cases of ELEYSO, PRX-102, and recombinant human intrinsic factor, have used a tobacco-based transient expression system (Table 1). In recent years, interest in transient expression has increased due to the containment of the system and the possibility of rapid upscaling due to the short interval between transformation and expression, which are attractive features for the industrial scale production and approval of the expressed products, e.g., the mass production of tobacco by Medicago and Kentucky BioProcessing. Pogue et al. [57] reviewed plant-based transient expression systems for the production of pharmaceutical-grade recombinant aprotinin and a monoclonal antibody product. Transient expression provides a safe and environmentally friendly system for both indoor and outdoor application with high speed and low cost of the genetic manipulation, rapid manufacturing cycles, and economical production. Transient production using an Agrobacterium tumefaciens-mediated transfer-DNA delivery system (Agro-infiltration) and/or virus-based replicating systems, the two dominant approaches, guarantees both the quality of the resulting purified products and the speed of development [57,58]. Spiegel et al. [59] demonstrate the application of the classical Nicotiana benthamiana/A. tumefaciens transient expression system to accelerate the development of a malaria vaccine candidate, with screens for expression, solubility, and stability using fluorescent fusion proteins. In Marin Viegas et al. [60], a transient expression system for the production of human TG2 in N. benthamiana leaves was optimized, and the reactivity of plant-produced TG2 in a CD screening test was evaluated. Hence, transient expression performed in contained facilities satisfies good manufacturing practices, and quick expression can avoid the time-consuming stable transformation [58,61]. In a comparison of productivity in terms of biomass production, Hiatt and Pauly [62] reported that grams of product may take only two weeks plus a few weeks more. In large-scale biomanufacturing systems, recombinant proteins can be produced at levels of $200-1000 \mathrm{mg} / \mathrm{kg}$ fresh weight tissue in as little as three months [57]. The transient expression of human Interleukin-6 in N. benthamiana (7.8\% TSP) produces 80-fold more than stable expression in tobacco plants $(0.3 \mathrm{mg} / \mathrm{g}$ fresh weight $(\mathrm{FW}))$ [63]. Conversely, hGAD65mut is expressed at higher levels in stable tobacco plants (143.6 $\mu \mathrm{g} / \mathrm{g}$ FW) than in N. benthamiana $(96.6 \mu \mathrm{g} / \mathrm{g} \mathrm{FW})$ [64]. This result suggests that expression potential or level varies case by case, depending on the target protein.

\section{Studies on Plant Vaccines}

In last decade, there has been a considerable increase in the use of transgenic plants to generate recombinant proteins for medical and veterinary use (Table 2). Research groups worldwide have attempted to develop more efficacious plant-derived vaccines for over 30 diseases, most frequently hepatitis B and influenza. In the case of hepatitis B, both stable and transient expression systems have been developed in various plants, including potato, lettuce, tobacco, tomato, carrot, and Arabidopsis for stable expression and N. benthamiana for transient expression. A detailed review of hepatitis B will be presented in the next part of this article. 
Table 2. Published studies on plant-derived antigens for last decade.

\begin{tabular}{|c|c|c|c|c|}
\hline Target Disease & Antigen & Host/Expression System & $\begin{array}{c}\text { Binary Vector/ } \\
\text { Agrobacterium Strain }\end{array}$ & Reference \\
\hline \multirow{9}{*}{ Malaria } & Multi-domain antigen & N. benthamiana/transient & pTRAkc-ERH/GV3101 & [59] \\
\hline & pfGAP50 & N. benthamiana/transient & pMP90RK/GV3101 & [65] \\
\hline & Pfs25, Pfs230_C0 & N. benthamiana/transient & pTRAkc-ERH/GV3101 & [66] \\
\hline & $\begin{array}{l}\text { Multi-domain antigen } \\
\text { (PfCSP, PfTRAP, } \\
\text { PfCelTOS) }\end{array}$ & N. benthamiana/transient & pMO90RK/GV3101 & [67] \\
\hline & Pf38 & N. benthamiana/transient & pTRAkc-ERH/GV3101 & [68] \\
\hline & Pfs 25 & N. benthamiana/transient & pGRD4/GV3101 & [69] \\
\hline & PfCP-2.9 & Tomato/transgenic & pPS1/LBA4404 & [70] \\
\hline & $\begin{array}{l}\text { PyMSP1 }_{19} \\
\text { Pfs } 230\end{array}$ & $\begin{array}{l}\text { N. benthamiana/transient } \\
\text { N. benthamiana/transient }\end{array}$ & $\begin{array}{c}\text { pICH11599/GV3101 } \\
\text { pGRD4/GV3101 }\end{array}$ & $\begin{array}{l}{[71]} \\
{[72]}\end{array}$ \\
\hline & PyMSP4/5 & N. benthamiana/transient & pICH11599/GV3101 & [73] \\
\hline \multirow{7}{*}{ HIV } & $2 \mathrm{G} 12$ & Rice endosperm/transgenic & pTRA/n.a. * & [74] \\
\hline & Gp120 and gp41 & N. tabacum/transplastomic & n.a. & [75] \\
\hline & p24 & $\begin{array}{l}\text { A. thaliana/transgenic } \\
\text { D. carota/transgenic }\end{array}$ & pGreen0229/EHA105 & [76] \\
\hline & $\begin{array}{c}\text { Multi-HIV } \\
\text { (gp120 and gp41) }\end{array}$ & N. tabacum/transplastomic & pKCZ-derived/n.a. & [77] \\
\hline & MPR of the gp41 & N. benthamiana/transgenic & pTM096/LBA4404 & [78] \\
\hline & Nef & N. tabacum/transgenic & pGreenII0179/GV3101 & [79] \\
\hline & $\mathrm{p} 17 / \mathrm{p} 24$ & N. benthamiana/transient & pTRAc/GV3101 & [80] \\
\hline \multirow{16}{*}{ Influenza } & $\begin{array}{c}\text { M2e } \\
\text { (extracellular domain of } \\
\text { matriz protein 2) }\end{array}$ & N. benthamiana/transient & pA7248AMV/GV3101 & [81] \\
\hline & $\begin{array}{c}\text { M2e } \\
\text { (ectodomain of } \\
\text { matrix protein 2) }\end{array}$ & Duckweed/transgenic & pBI121/n.a. & [82] \\
\hline & H5 HA & Arabidopsis/transformation & 326-Bip/n.a. & [83] \\
\hline & $\begin{array}{c}\text { H5 HA } \\
\text { (H5 Hemagglutinin) }\end{array}$ & N. benthamiana/transient & n.a./GV3101 & [84] \\
\hline & H1 \& H5 HA & N. benthamiana/transient & n.a. & [85] \\
\hline & H7 HA & N. benthamiana/transient & n.a. & [86] \\
\hline & H1 \& H5 HA & N. benthamiana/transient & n.a. & [87] \\
\hline & HA & N. benthamiana/transient & n.a. & [88] \\
\hline & HA & N. benthamiana/transient & pGRD4/GV3101 & [89] \\
\hline & HAC1 & N. benthamiana/transient & n.a. & [90] \\
\hline & H5 HA & N. benthamiana/transient & pTRA/GV3101 & [91] \\
\hline & H1 HA & N. benthamiana/- & n.a. & [92] \\
\hline & M2eHBc & N. benthamiana/transient & pGEM/GV3101 & [93] \\
\hline & H5 HA & N. benthamiana/transient & n.a. & [94] \\
\hline & H3 HA & N. benthamiana/transient & pBID4/GV3101 & [95] \\
\hline & H3 HA & N. benthamiana/transient & pBID4/GV3101 & [96] \\
\hline \multirow{2}{*}{ Avian influenza } & rHA0 & N. benthamiana/transient & magnICON, TMV & [97] \\
\hline & Hemagglutinin M2 & N. benthamiana/transient & CMV & [98] \\
\hline \multirow{6}{*}{ Foot-and-mouth disease } & VP1 & N. benthamiana cell/stable & pBVP1/GV3850 & [99] \\
\hline & VP1 & Soybean/transient & pSYCMV-FMDV & [100] \\
\hline & FMDV VP1 & Crotalaria/transgenic & n.a. & [101] \\
\hline & VP1 & Rice/transgenic & n.a. & [102] \\
\hline & P1-2A3C & Tomato/transgenic & pBin438/GV3101 & [103] \\
\hline & FMDV VP1 & $\begin{array}{c}\text { Chenopodium quinoa } \\
\text { (C. quinoa)/ } \\
\text { N. benthamiana/transient }\end{array}$ & CMV-based pBVP1 & [104] \\
\hline
\end{tabular}


Table 2. Cont

\begin{tabular}{|c|c|c|c|c|}
\hline Target Disease & Antigen & Host/Expression System & $\begin{array}{c}\text { Binary Vector/ } \\
\text { Agrobacterium Strain }\end{array}$ & Reference \\
\hline \multirow{4}{*}{ Colorectal cancer } & GA733-Fc & N. tabacum/transgenic & T-easy/LBA4404 & [105] \\
\hline & GA733-FcK & N. tabacum/transgenic & pBIN-Plus/LBA4404 & [106] \\
\hline & $\begin{array}{l}\text { GA733K, GA733-FcK, } \\
\text { and GA733-Fc }\end{array}$ & N. tabacum/transgenic & pBIN-Plus/LBA4404 & [107] \\
\hline & GA733 & $\begin{array}{l}\text { N. tabacum/transgenic } \\
\text { Beta vulgaris/transient }\end{array}$ & $\begin{array}{l}\text { pBIN-Plus/LBA4404 } \\
\text { pICH11599/GV3101 }\end{array}$ & {$[108]$} \\
\hline Mosaic diseases & ALSV and BYMV & N. benthamiana/- & n.a. & [109] \\
\hline \multirow[b]{2}{*}{ Anthrax } & PA (Protective antigen) & Tobacco/transgenic & pCHV-RKB/n.a. & [110] \\
\hline & $\begin{array}{c}\text { PA (dIV) } \\
\text { (Protective antigen } \\
\text { Domain IV) }\end{array}$ & n.a. & pCambia1303/GV2260 & [111] \\
\hline $\begin{array}{c}\text { Polysaccharide } \\
\text { encapsulated bacteria }\end{array}$ & cps3S & N. tabacum/transgenic & pCambia2301/GV3101 & [112] \\
\hline Atherosclerosis & ApoB100, CETP & N. tabacum/transgenic & n.a. & [113] \\
\hline West Nile Virus (WNV) & $\begin{array}{l}\text { Domain III (DIII) of } \\
\text { WNV E protein }\end{array}$ & N. benthamiana/transient & $\begin{array}{l}\text { pIC11599 of the } \\
\text { MagnICON } \\
\text { system/GV3101 }\end{array}$ & [114] \\
\hline Hemophilia & Factor VIII (FVIII) & N. tabacum/transgenic & pLD-CTB/n.a. & [115] \\
\hline \multirow[b]{2}{*}{ Swine edema } & Shiga toxin 2e B (Stx2e) & L. sativa/transgenic & pBI121/n.a. & [116] \\
\hline & Shiga toxin 2e B & $\begin{array}{c}\text { L. sativa/transgenic, } \\
\text { transient } \\
\text { N. tabacum/transgenic, } \\
\text { transient }\end{array}$ & pBI121/n.a. & [117] \\
\hline $\begin{array}{c}\text { Hemorrhagic colitis \& } \\
\text { hemolytic-uremic } \\
\text { syndrome } \\
\text { (Escherichia coli O157:H7) }\end{array}$ & EIT & N. tabacum/transgenic & pVSR326/n.a. & [118] \\
\hline \multirow{3}{*}{ Cholera } & СТВ & O. sativa/transgenic & pZ2028/n.a. & [119] \\
\hline & CTB-As16 & O. sativa/transgenic & pGTV/EHA105 & [120] \\
\hline & CTB-FimA & S. tuberosum/transgenic & pPCV701/n.a. & [121] \\
\hline Infectious Bursal Disease & VP2 & N. benthamiana/transient & pBINPLUS/n.a. & [122] \\
\hline $\begin{array}{l}\text { Bovine rotavirus } \\
\text { infection }\end{array}$ & VP8 & N. tabacum/transgenic & pBSW-utr/n.a. & [123] \\
\hline RHD & VP60 & S. tuberosum/transgenic & pGK/LBA4404 & [124] \\
\hline Diarrhea & Rotavirus VP6 & C. amaranticolor/transgenic & pGEM/n.a. & [125] \\
\hline \multirow[b]{2}{*}{ Bovine viral diarrhea } & E2 & M. sativa/transgenic & pBI121/LBA4404 & [126] \\
\hline & $\begin{array}{l}\text { (tE2) truncated version } \\
\text { of the glycoprotein E2 }\end{array}$ & N. tabacum/transient & pK7WG2/EHA105 & [127] \\
\hline \multirow{3}{*}{ Heat labile toxin } & $\begin{array}{l}\text { B subunit of the heat } \\
\text { labile toxin (LTB) }\end{array}$ & $\begin{array}{l}\text { N. benthamiana/transient } \\
\text { P. parodii/transgenic }\end{array}$ & pBinPlus/n.a. & [128] \\
\hline & LTB & $\begin{array}{l}\text { N. tabacum/transgenic } \\
\text { P. Parodii/transgenic } \\
\text { S. lycopersicum/transgenic }\end{array}$ & pBinPlus/LBA9402 & [129] \\
\hline & LTB & $\begin{array}{l}\text { N. benthamiana/transient } \\
\text { P. parodii/transgenic } \\
\text { S. lycopersicum/transgenic }\end{array}$ & $\begin{array}{l}\text { pICH11599/GV3101 } \\
\text { pBinPlus/LBA9402 } \\
\text { pCLTB/EHA105 }\end{array}$ & [130] \\
\hline Coccidiosis & EtMIC1 and EtMIC2 & N. tabacum/transient & pTRA ERH/GV3101 & [131] \\
\hline
\end{tabular}


Table 2. Cont.

\begin{tabular}{|c|c|c|c|c|}
\hline Target Disease & Antigen & Host/Expression System & $\begin{array}{c}\text { Binary Vector/ } \\
\text { Agrobacterium Strain }\end{array}$ & Reference \\
\hline PRRS & $\begin{array}{l}\text { PRRSV matrix }(\mathrm{M}) \\
\text { protein }\end{array}$ & Maize callus/transgenic & pAHC25/n.a. & [132] \\
\hline \multirow{3}{*}{$\mathrm{HPV}$} & HPV16 & N. benthamiana/transient & pBID4/GV3101 & [133] \\
\hline & $\begin{array}{c}\text { HPV16 L1 } \\
\text { (fused with LTB) }\end{array}$ & N. tabacum/transgenic & pPNG1014_MCS120/n.a. & [134] \\
\hline & HPV16 E7 & $\begin{array}{l}\text { N. tabacum/transgenic } \\
\text { N. benthamiana/transient }\end{array}$ & pBID4/A4 & [135] \\
\hline \multirow{3}{*}{ Gastroenteritis } & VP4 and VP7 & N. benthamiana/transient & n.a. & [136] \\
\hline & $\begin{array}{c}\text { OmpA of } \\
\text { Salmonella typhimurium }\end{array}$ & Alfalfa/transgenic & pBI121/LBA4404 & [137] \\
\hline & VP7 & S. tuberosum/transgenic & pBI121/LBA4404 & [45] \\
\hline $\begin{array}{l}\text { Peptic ulceration and } \\
\text { gastric cancer } \\
\text { (Helicobacter pylori) }\end{array}$ & Helicobacter pylori TonB & A. thaliana/transgenic & pPCV742/n.a. & [138] \\
\hline \multirow{7}{*}{ Plague } & $\begin{array}{l}\mathrm{F} 1 \text { and } \mathrm{V} \text { antigens } \\
\text { from } Y \text {. pestis }\end{array}$ & Lettuce/transgenic & pBI121/LBA4404 & [139] \\
\hline & F1-V & S. lycopersicum/transgenic & n.a. & [140] \\
\hline & F1-V & N. benthamiana/transgenic & n.a. & [141] \\
\hline & F1-V & N. tabacum/transgenic & pLD/n.a. & [142] \\
\hline & F1 and LcrV & N. benthamiana/transient & $\mathrm{pBID} 4 / \mathrm{A} 4$ & [143] \\
\hline & F1-V & $\begin{array}{l}\text { N. benthamiana/transient } \\
\text { L. esculentum/transgenic }\end{array}$ & pGPTV/LBA4404 & [144] \\
\hline & F1-V & N. benthamiana/transient & pICH11599/n.a. & [43] \\
\hline \multirow{3}{*}{ Tuberculosis } & Ag85B/ESAT-6 & N. tabacum/transgenic & pGEM(T)-easy/C58C1 & [145] \\
\hline & ESAT6:Ag85B & N. benthamiana/transient & pBin19/GV3101 & [146] \\
\hline & ESAT-6 & A. thaliana/transgenic & n.a. & [147] \\
\hline Newcastle disease & $\begin{array}{l}\text { (HN) Hemagglutinin } \\
\text { neuraminidase }\end{array}$ & N. tabacum/transgenic & n.a. & [148] \\
\hline Avian reovirus & $\sigma \mathrm{C}$ & A. thaliana/transgenic & n.a. & [149] \\
\hline $\begin{array}{l}\text { Diphtheria Tetanus } \\
\text { Pertussis (DTP) }\end{array}$ & $\begin{array}{c}\text { DT (diphtheria toxin) } \\
\text { TetC (fragment C antigen) } \\
\text { PTX S1 } \\
\text { (subunit S1 antigen) }\end{array}$ & $\begin{array}{l}\text { N. tabacum /transgenic } \\
\text { D. carota/transgenic }\end{array}$ & pBinPlus/LBA4404 & [150] \\
\hline $\begin{array}{l}\text { RSV (Respiratory } \\
\text { Syncytial Virus) }\end{array}$ & RSV-F & S. lycopersicum/transgenic & pJSS-4/n.a. & [151] \\
\hline Poxvirus infection & pB5 & N. benthamiana/transient & n.a./GV3101 & [152] \\
\hline SARS & S1 & $\begin{array}{l}\text { Tobacco/transgenic } \\
\text { Lettuce/transgenic }\end{array}$ & n.a. & [153] \\
\hline Follicular lymphoma & $\begin{array}{c}\text { Idiotypic Ig } \\
\text { (tumor-specific antigen) }\end{array}$ & N. benthamiana/transient & magnICON/ICF 320 & [154] \\
\hline
\end{tabular}

* n.a.: Not available; HIV, Human Immunodeficiency; FMDV, Foot-and-mouth disease virus; EIT, Trivalent recombinant protein; CTB, Cholera toxin B subunit; RHD, Rabbit haemorrhagic disease (RHD); HPV, Human papillomavirus; SARS, Severe acute respiratory syndrome.

Influenza is also a main target of this field because it is a widely distributed viral infection of humans and animals, and a new epidemic strain appears every one to two years. This pattern requires the production of new vaccines at the same frequency, and a promising solution is to establish a rapid, flexible, and safe system. The production of various antigens such as hemagglutinin (HA) and the extracellular domain of matrix protein 2 (M2e) has mainly focused on transient expression systems using N. benthamiana leaves. Using the Medicago "Proficia" ${ }^{\mathrm{TM}}$ " system, vaccine production can be initiated within less than three weeks from the identification of the genetic sequence of a pandemic or seasonal influenza strain [155]. 
Vamvaka et al. [74] reported the development of transgenic rice plant expressing the HIV-neutralizing antibody $2 \mathrm{G} 12$ in the endosperm (42 $\mu \mathrm{g} / \mathrm{g}$ dry seed weight) to evaluate the potential of rice seeds as a vehicle for inexpensive microbicide production. Production is higher than the initial achievement of maize-derived 2G12 (30 $\mu \mathrm{g} / \mathrm{g})$ by Rademacher et al. [156]. Rubio-Infante et al. [75] demonstrated the immunogenic potential of tobacco chloroplast-derived multi-HIV in an oral immunization scheme and proposed it as a vaccine prototype capable of inducing broad immune responses as it carries various B and T cell epitopes from several HIV strains.

Dengue has become a significant public health problem, and the threat of Dengue fever is now increasing in temperate regions due to dramatic climate change. The rice codon-optimized consensus domain III of dengue virus envelope glycoprotein (E) has been fused to the M cell-binding peptide via agroinfiltration with a plant virus-based expression system [157-159]. Carrying these results a step further, Kim et al. [159] generated an Ebola RIC-based DENV vaccine in tobacco plants using a geminiviral vector expression system and reported its immunogenic properties as a self-adjuvanting dengue vaccine candidate. Previously, Phoolcharoen et al. [160] reported that plant-expressed Ebola RIC protected mice against a lethal Ebola virus challenge.

The expression of subunit vaccines for animal viral diseases, such as avian influenza $[98,161]$, foot-and-mouth disease (FMD) [100-102], and diarrhea [123,126,127], which are considered to be the most important causes of economic losses in plants, has been frequently reported. The commercialization of veterinary vaccine is relatively easy compared with that of human vaccines. To date, four cases in clinical trials are ready to enter the market. Recombinant plant viral hamagglutinin-neuraminidase (HN) protein of the Newcastle disease virus (approved by United States Department of Agriculture (USDA)) and a mixture of antiviral vaccines have been prepared by Dow Agro Sciences. A plant anti-rabies vaccine (completion of phase I) has been developed by Thomas Jefferson University. Chicken coccidiosis is in the second phase of clinical trials run by the Canadian Guardian Biosciences company. For the FMD vaccine, N. benthamiana, tomato, and rice have been used for both transient and stable transformation. Most recently, Muthamilselvan et al. [99] have presented an important advance with $2.1 \mathrm{mg} / 20 \mathrm{~g}$ fresh weight of plant callus-based biomass in the cost-effective large-scale production of immunopeptide vaccines against FMD. They established transgenic cell-suspension cultures from $N$. benthamiana leaves expressing FMDV VP1 and gene silencing suppressor $\mathrm{p} 19$ and then validated the efficacy using immunized guinea pigs that produced humoral antibodies. Lim et al. [100] developed an SYCMV-derived vector containing FMDV VP1, which was expressed successfully in soybean plants by infiltration.

Diarrhea, a representative infectious disease caused by rotavirus and diarrhea virus, is also being studied. Various groups have expressed rotavirus capsid proteins (VP2, $-4,-6,-7$, and -8 ) in plants. Most studies have introduced VP6, which forms the intermediate capsid, as a vaccine epitope into different plant species, including $N$. benthamiana, tomato, and Medicago sativa. Pera et al. [162] suggest that the highly immunogenic VP8 epitopes produced in N. benthamiana are candidates for a subunit vaccine, specifically for the G9P rotavirus strain.

\section{Production of HBV Antigens in a Plant System}

The greatest problem of plant-derived vaccine development is the extremely low expression level of the foreign protein in plants. For this reason, many researchers have studied how to improve protein expression levels in plants. In the case of plant-derived HBV vaccines, the first report was on the expression of the small hepatitis B surface antigen (S-HBsAg) in transgenic tobacco plants. In this report, the HBsAg produced in transgenic tobacco was antigenically and physically similar to the HBsAg particles derived from human serum and recombinant yeast [163]. Afterward, many research groups attempted HBsAg expression in different tissues and plant species, such as tobacco, potato, lettuce, soybean, lupine, maize, tomato, peanut and Laminaria japonica (Table 3). In the transgenic tobacco plant transformed with the S-HBsAg gene controlled by the $35 \mathrm{~S}$ promoter, expression levels were very low: less than $0.01 \%$ total soluble protein and less than $10 \mathrm{ng} / \mathrm{g}$ fresh weight in leaf tissues. The expression 
levels of S-HBsAg in other plant species were not significantly higher; in some species, expression levels were even lower than in tobacco. To improve vaccine production in plants, the most widely used strategies involve: (1) suitable promoters, such as strong constitutive promoters, tissue-specific promoters and promoters that are inducible by environmental factors; (2) targeting systems to specific organelles; (3) optimized codon usage; (4) alternative polyadenylation signals; (5) increased translation efficiency using leader sequences; and (6) different vector systems. Many HBsAg-overexpressing transgenic plants have been developed using strong constitutive promoters, such as the $35 \mathrm{~S}$ promoter with enhancer [164-166]. In addition to tissue-specific promoters, the patatin promoter for potato tuber $[165,167]$, globulin promoter for maize seed $[168]$ and fruit-specific promoters $[169,170]$ were used. Specific organelle-, endoplasmic reticulum (ER)-, vacuole- and chloroplast-targeted strategies have also been tried $[167,171]$.

The HBsAg has been expressed in non-edible plants, such as tobacco, using four different expression cassettes: the HBsAg gene without ER retention signal (HBS), the HBsAg gene with ER retention signal (HER), and each gene controlled by the ubiquitin promoter (UBQ) or ethylene forming enzyme promoter (EFE) [172]. In this report, the maximum expression level $(19.4 \mathrm{ng} / \mathrm{g}$ FW of leaves) was observed in EFE-HBS transformed plant growth in vitro, but a higher proportion of the particulate form of the antigen was observed when it was expressed with an ER retention signal. The EFE promoter is more effective in in vitro-cultured plantlets, whereas the UBQ promoter is more effective in greenhouse-grown plantlets. The maximum expression level was $2 \mu \mathrm{g} / \mathrm{g} F W$ in the UBQ-HER transformed NT-1 cell suspension culture [173]. The expression level was increased up to $8 \mu \mathrm{g} / \mathrm{g}$ FW using HBsAg fused with the $3^{\prime}$ region from the soybean vegetative storage protein gene and was controlled by a chimeric ocs-mas promoter. Upon transformation into a soybean cell culture using the same vector, the maximum expression level was $74 \mu \mathrm{g} / \mathrm{g}$ FW [174]. 
Table 3. Published studies on plant-derived hepatitis B virus (HBV) antigens and expression levels.

\begin{tabular}{|c|c|c|c|c|c|c|}
\hline Antigen & $\begin{array}{c}\text { Host Plant/ } \\
\text { Expression System }\end{array}$ & $\begin{array}{c}\text { Binary Vector/ } \\
\text { Agrobacterium Strain }\end{array}$ & Promoter/Targeting & Maximum Yield & Application and Results & Reference \\
\hline \multirow{19}{*}{ S-HBsAg } & N. tabacum/transgenic & pBI121/LBA4404 & 35S/n.a. * & $0.01 \%$ of TSP & Injection, IgA, IgG and IgM antibodies in serum & {$[163,175]$} \\
\hline & N. tabacum/transgenic & pGA482/LBA4404 & 35S/n.a. & $0.05 \%$ of TSP & n.a. & [176] \\
\hline & N. tabacum/transgenic & pBI121/EHA105 & $U B Q 3 / E R$ & 20 ng/g FW & n.a. & [172] \\
\hline & N. tabacum/transgenic & pKHBSBAR/EHA105 & 35S/n.a. & $10 \mu \mathrm{g} / \mathrm{g} \mathrm{FW}$ & $\begin{array}{l}\text { Injection, IgG antibodies in serum } \\
\text { (maximum } 765 \mathrm{mIU} / \mathrm{mL})\end{array}$ & {$[177,178]$} \\
\hline & N. tabacum/transgenic & pE1802,pE1945/LBA4404 & (Aocs) $)_{3}$ AmasPmas/n.a. & $0.06 \%$ of TSP & n.a. & [179] \\
\hline & N. tabacum/transgenic & pAMPAT-MCS/GV3101 & D35S/n.a. & $2-26 \mathrm{ng} / \mathrm{g} \mathrm{FW}$ & Oral, IgA, IgG antibodies in serum & {$[26,180]$} \\
\hline & N. tabacum/transgenic & pBM/LBA4404 & D35S/n.a. & $0.01 \%-0.05 \%$ of TSP & n.a. & [181] \\
\hline & N. benthamiana/transient & pICH11599/GV3101 & Act2/ER & 295 нg/g FW & $\begin{array}{l}\text { Injection, IgG antibodies in serum } \\
\text { (maximum } 830 \mathrm{mIU} / \mathrm{mL})\end{array}$ & [30] \\
\hline & N. benthamiana/transient & pIBT210/LBA4404 & 35S/n.a. & $0.05 \%$ of TSP & $\begin{array}{l}\text { Injection, IgA and IgG antibodies in serum } \\
\text { (maximum } 346 \mathrm{mIU} / \mathrm{mL})\end{array}$ & [182] \\
\hline & NT-1 cell/transgenic & pBI121/EHA105 & UBQ3/ER & $2 \mu \mathrm{g} / \mathrm{g} F W$ & n.a. & [173] \\
\hline & NT-1 cell/transgenic & pBI121/EHA105 & UBQ3/ER & $\begin{array}{l}31 \mu \mathrm{g} / \mathrm{L} \text { culture } \\
\text { medium }\end{array}$ & n.a. & [183] \\
\hline & NT-1 cell/transgenic & pHB155/n.a. & D35S/n.a. & $\begin{array}{l}8 \mu \mathrm{g} / \mathrm{g} \text { FW }(2 \mathrm{mg} / \mathrm{L} \\
\text { culture medium })\end{array}$ & n.a. & [174] \\
\hline & NT-1 cell/transgenic & pGPTV-KAN/LBA4404 & 35S/ER & $0.005 \%-0.023 \%$ of TSP & $\begin{array}{l}\text { Injection, IgG antibodies in serum } \\
\text { (maximum } 4 \mathrm{mIU} / \mathrm{mL} \text { ) }\end{array}$ & [184] \\
\hline & Potato/transgenic & pDES20/GV3101 & D35S/n.a. & $1 \mu \mathrm{g} / \mathrm{g}$ FW (tuber) & n.a. & [164] \\
\hline & Potato/transgenic & pBI101/LBA4404 & 35S/n.a. & $6 \mu \mathrm{g} / \mathrm{g}$ FW (tuber) & Injection & [185] \\
\hline & Potato/transgenic & pBI101/LBA4404 & PAT/n.a. & 1.1 нg/g FW (tuber) & $\begin{array}{l}\text { Oral, IgG antibodies in serum } \\
\text { (maximum } 1680 \mathrm{mIU} / \mathrm{mL} \text { ) }\end{array}$ & [165] \\
\hline & Potato/transgenic & pHB114/LBA4404 & 35S/n.a. & $11 \mu \mathrm{g} / \mathrm{g}$ FW (tuber) & $\begin{array}{l}\text { Oral, IgG antibodies in serum } \\
\text { (maximum } 4785 \mathrm{mIU} / \mathrm{mL} \text { ) }\end{array}$ & [41] \\
\hline & Potato/transgenic & pBI121/LBA4404 & PAT/n.a. & $0.09 \%$ of TSP (tuber) & $\begin{array}{l}\text { Oral, IgG antibodies in serum } \\
\text { (maximum } 800 \mathrm{mIU} / \mathrm{mL} \text { ) }\end{array}$ & [167] \\
\hline & Potato/transgenic & pHB114/LBA4404 & 35S/n.a. & 8.35 нg/g FW (tuber) & $\begin{array}{l}\text { Oral, IgG antibodies in serum } \\
\text { (maximum } 3300 \mathrm{mIU} / \mathrm{mL} \text { ) }\end{array}$ & [166] \\
\hline
\end{tabular}


Table 3. Cont

\begin{tabular}{|c|c|c|c|c|c|c|}
\hline Antigen & $\begin{array}{c}\text { Host Plant/ } \\
\text { Expression System }\end{array}$ & $\begin{array}{c}\text { Binary Vector/ } \\
\text { Agrobacterium Strain }\end{array}$ & Promoter/Targeting & Maximum Yield & Application and Results & Reference \\
\hline \multirow{18}{*}{ S-HBsAg } & Potato/transgenic & pBM/LBA4404 & D35S/n.a. & $0.05 \%$ of TSP (tuber) & $\begin{array}{l}\text { Oral, IgG antibodies in serum (maximum } 350 \\
\mathrm{mIU} / \mathrm{mL} \text { ) }\end{array}$ & [186] \\
\hline & Potato/transgenic & pBM/LBA4404 & 35S/n.a. & $1 \mu \mathrm{g} / \mathrm{g}$ FW (tuber) & $\begin{array}{l}\text { Oral, IgG antibodies in serum (maximum } 350 \\
\mathrm{mIU} / \mathrm{mL} \text { ) }\end{array}$ & [186] \\
\hline & Lettuce/transgenic & pROK/LBA4404 & 35S/n.a. & $5.5 \mathrm{ng} / \mathrm{g}$ FW & n.a. & [187] \\
\hline & Lettuce/transgenic & pGPTV-BAR/EHA105 & 35S/n.a. & $60 \mu \mathrm{g} / \mathrm{g}$ FW & $\begin{array}{l}\text { Oral, IgA and IgG antibodies in serum } \\
\text { (maximum } 38 \mathrm{mIU} / \mathrm{mL} \text { ), } \\
\text { Oral (PBS-suspended lyophilized tissue), } \\
\text { IgG antibodies in serum } \\
\text { (maximum } 300 \mathrm{mIU} / \mathrm{mL} \text { ) }\end{array}$ & {$[188,189]$} \\
\hline & A. thaliana/transgenic & pAMPAT-MCS/GV3101 & D35S/n.a. & 3-15 ng/g FW & Oral, IgA, IgG antibodies in serum & {$[26,180]$} \\
\hline & Soybean cell/transgenic & pHB155 vector/n.a. & D35S/n.a. & $\begin{array}{c}(74 \mu \mathrm{g} / \mathrm{g} \mathrm{FW}) \\
22 \mathrm{mg} / \mathrm{L} \text { culture } \\
\text { medium }\end{array}$ & n.a. & [174] \\
\hline & Soybean cell/transgenic & pMSI164/EHA105 & UBQ3/ER & 700 ng/g FW & n.a. & [190] \\
\hline & Banana/transgenic & pBI121/EHA105 & EFE ER & 38 ng/g FW (leaf) & n.a. & [191] \\
\hline & Lupin/transgenic & $\mathrm{pROK} / \mathrm{C} 58$ & 35S/n.a. & 150 ng/g FW (Callus) & $\begin{array}{l}\text { Oral, IgG antibodies in serum } \\
\text { (maximum } 19 \mathrm{mIU} / \mathrm{mL} \text { ) }\end{array}$ & [187] \\
\hline & Lupin/transgenic & $\begin{array}{l}\text { pROK/GV3101, EHA105, } \\
\text { LBA4404 }\end{array}$ & 35S/n.a. & $\begin{array}{l}2.5-6 \mu \mathrm{g} / \mathrm{g} \mathrm{FW} \\
\text { (Callus) }\end{array}$ & n.a. & [192] \\
\hline & Maize/transgenic & n.a./EHA101 & 3xglb1/Cell wall & $0.51 \%$ of TSP (seed) & n.a. & [168] \\
\hline & Maize/transgenic & n.a./EHA101 & Glob1/Cell wall & $0.46 \%$ of TSP (seed) & $\begin{array}{l}\text { Oral (germ, bioencapsulated), IgA and IgG } \\
\text { antibodies in serum (maximum } 4632 \mathrm{mIU} / \mathrm{mL} \text { ) }\end{array}$ & [193] \\
\hline & Maize/transgenic & n.a./EHA101 & 3kbglb1/Cell wall & $0.41 \%$ of TSP (seed) & $\begin{array}{l}\text { Oral (germ, wafer feeding), IgA and IgG } \\
\text { antibodies in serum }\end{array}$ & [194] \\
\hline & Maize/transgenic & n.a./EHA101 & Glob1/Cell wall & $0.46 \%$ of TSP (seed) & $\begin{array}{l}\text { Oral (germ, wafer feeding), IgA and IgG } \\
\text { antibodies in serum }\end{array}$ & [195] \\
\hline & $\begin{array}{c}\text { Cherry } \\
\text { tomatillo/transgenic }\end{array}$ & pCAMBIA1301/EHA105 & 35S/n.a. & 10 ng/g FW (fruit) & Oral, IgG antibodies in serum & [196] \\
\hline & Tomato/transient & pBI121/EHA105 & EFE/ER & $0.5 \mu \mathrm{g} / \mathrm{g}$ DW (leaf) & n.a. & [169] \\
\hline & Tomato/transgenic & pBINPLUS-ARS/LBA4404 & 35S/ER & n.a. & n.a. & [191] \\
\hline & Tomato/transgenic & $\mathrm{pBM} / \mathrm{LBA} 4404$ & D35S/n.a. & $\begin{array}{l}0.01 \%-0.05 \% \text { of } \\
\text { TSP (leaf) }\end{array}$ & n.a. & [181] \\
\hline
\end{tabular}


Table 3. Cont.

\begin{tabular}{|c|c|c|c|c|c|c|}
\hline Antigen & $\begin{array}{l}\text { Host Plant/ } \\
\text { Expression System }\end{array}$ & $\begin{array}{c}\text { Binary Vector/ } \\
\text { Agrobacterium Strain }\end{array}$ & Promoter/Targeting & Maximum Yield & Application and Results & Reference \\
\hline \multirow{5}{*}{ S-HBsAg } & Tomato/transgenic & pCAMBIA1301/EHA105 & 35S/n.a. & n.a. & n.a. & [197] \\
\hline & Tomato/transgenic & pBINPLUS-ARS/LBA4404 & 35S/n.a. & $0.3 \mu \mathrm{g} / \mathrm{g}$ DW (fruit) & $\begin{array}{l}\text { Oral, IgA and IgG antibodies in serum } \\
\text { (maximum } 300 \mathrm{mIU} / \mathrm{mL} \text { ) }\end{array}$ & [193] \\
\hline & Carrot cell/transgenic & pPCV812/n.a. & MAS/n.a. & 25 ng/g FW & n.a. & [198] \\
\hline & $\begin{array}{c}\text { Laminaria } \\
\text { japonica/transgenic }\end{array}$ & pCAT/n.a. & SV40/n.a. & $0.05 \%-0.25 \%$ of TSP & n.a. & [199] \\
\hline & Peanut/transgenic & pCAMBIA1301/EHA105 & 35S/n.a. & 240 ng/g FW (bud) & Injection & [200] \\
\hline \multirow{8}{*}{ M-HBsAg } & N. tabacum/transgenic & n.a. & n.a. & $10 \mu \mathrm{g} / \mathrm{g}$ FW & $\begin{array}{l}\text { Injection, IgG antibodies in serum } \\
\text { (maximum } 1165 \mathrm{mIU} / \mathrm{mL} \text { ) }\end{array}$ & [177] \\
\hline & Tobacco/transgenic & pGPTV-BAR/EHA105 & 35S/n.a. & $12-21 \mu \mathrm{g} / \mathrm{g} F W$ & n.a. & [201] \\
\hline & N. benthamiana/transient & pIBT210/LBA4404 & 35S/n.a. & $0.04 \%$ of TSP & $\begin{array}{l}\text { Injection, IgA and IgG antibodies in serum } \\
\text { (maximum } 1165 \mathrm{mIU} / \mathrm{mL} \text { ) }\end{array}$ & [182] \\
\hline & Potato/transgenic & pBI121/LBA4404 & PAT/n.a. & $0.012 \%$ of TSP (tuber) & $\begin{array}{l}\text { Oral, IgG antibodies in serum } \\
\text { (maximum } 800 \mathrm{mIU} / \mathrm{mL} \text { ), Oral, IgA and IgG } \\
\text { antibodies in serum (maximum } 558 \mathrm{mIU} / \mathrm{mL} \text { ) }\end{array}$ & {$[167,202]$} \\
\hline & Lettuce/transgenic & pGPTV-BAR/EHA105 & 35S/n.a. & $2-23 \mu \mathrm{g} / \mathrm{g}$ FW & n.a. & [201] \\
\hline & Tomato/transgenic & pBINPLUS-ARS/LBA4404 & 35S/n.a. & $0.002 \%$ of TSP (fruit) & n.a. & [203] \\
\hline & Tomato/transgenic & pBINPLUS-ARS/AGLO & 35S/n.a. & $\begin{array}{l}0.003 \%-0.021 \% \text { of } \\
\text { TSP (fruit) }\end{array}$ & $\begin{array}{l}\text { Oral (freeze-dried material), } \\
\text { IgG antibodies in serum }\end{array}$ & {$[204,205]$} \\
\hline & Carrot/transgenic & pBINPLUS-ARS/n.a. & 35S/ER & 42 ng/g FW (leaf) & n.a. & [206] \\
\hline \multirow{3}{*}{ L-HBsAg } & Tobacco/transgenic & pGPTV-BAR/EHA105 & 35S/n.a. & $4-13 \mu \mathrm{g} / \mathrm{g} \mathrm{FW}$ & n.a. & [201] \\
\hline & Lettuce/transgenic & pGPTV-BAR/EHA105 & 35S/n.a. & $3-20 \mu \mathrm{g} / \mathrm{g}$ FW & n.a. & [201] \\
\hline & Tomato/transgenic & pYPX143/LBA4404 & 2A11/n.a. & $0.5 \mu \mathrm{g} / \mathrm{g}$ FW (Fruit) & n.a. & [171] \\
\hline \multirow{5}{*}{$\begin{array}{l}\text { Hepatitis B } \\
\text { core antigen }\end{array}$} & N. tabacum/transgenic & pBIN19/LBA4404 & $\mathrm{E} 12 \Omega /$ n.a. & $24 \mu \mathrm{g} / \mathrm{g}$ FW & n.a. & [207] \\
\hline & N. tabacum/transient & pICH11599/GV3101 & 35S/n.a. & $2.38 \mathrm{mg} / \mathrm{g} \mathrm{FW}$ & $\begin{array}{c}\text { Injection and Oral, } \\
\text { IgA and IgG antibodies in serum }\end{array}$ & [208] \\
\hline & N. benthamiana/transient & pBINPLUS/LBA4404 & 35S/n.a. & $1 \mathrm{mg} / \mathrm{g}$ FW & n.a. & [209] \\
\hline & N. benthamiana/transient & pBY023/LBA4404 & 35S/n.a. & $0.18 \mathrm{mg} / \mathrm{g} \mathrm{FW}$ & n.a. & [210] \\
\hline & N. benthamiana/transient & pEAQ-HT/LBA4404 & 35S/n.a. & $0.2-1 \mathrm{mg} / \mathrm{g} \mathrm{FW}$ & n.a. & [211] \\
\hline
\end{tabular}

* n.a.: Not available; TSP, total soluble protein; UBQ3, ubiquitin 3; ER, endoplasmic reticulum; FW, fresh weight; PAT, patatin; PBS, phosphate buffered saline; EFE, ethylene-forming enzyme; DW, dry weight. 
HBsAg has been expressed in vegetative crops, such as potato, tomato, soybean and lettuce. The expression level of transgenic potato tubers was 1-11 $\mu \mathrm{g} / \mathrm{g}$ FW. The highest expression in a tuber was developed using a construct driven by the CaMV 35 S promoter with dual enhancers, the tobacco etch virus $5^{\prime}$-UTR, and the $3^{\prime}$ region from the soybean vegetative storage protein gene [165]. Expression level of HBV-protein in potato was little increased when controlled by the tuber specific promoter [167]. Target DNA is inserted into a genomic DNA as a random event when a using Agrobacterium-mediated transformation. For this reason, it is difficult to conclude what is the best method for increase of HBV-protein expression level because differences in the expression level between the transgenic lines even with the same vector construction. Expression in tomato fruit has been reported at $0.5 \mu \mathrm{g} / \mathrm{g}$ dry weight. To achieve a higher level of expression, several strong and inducible promoters, such as the enhanced dual 35S, UBQ and EFE promoters, were tested, as well as organelle targeting sequences. The greatest improvement resulted from the HBsAg gene with an ER retention signal controlled by EFE promoter [169]. Sunil Kumar et al. [170] reported HBsAg transformation in banana. The maximum expression in banana leaves has been reported at $38 \mathrm{ng} / \mathrm{g}$ FW. The expression levels in banana fruits were not presented in this report, but the expression level was presumably lower than in the leaf tissue. As with leafy vegetables, a variety of expression technologies have not yet been applied. In lettuce, the maximum expression level was $60 \mu \mathrm{g} / \mathrm{g}$ FW, which is the maximum anti-HBsAg antibody titer of $300 \mathrm{mIU}$ in immunized mice serum $[188,189,201]$. Upon transformation into a soybean cell culture using a construct of HBsAg fused with the $3^{\prime}$ region from the soybean vegetative storage protein gene and as controlled by a chimeric ocs-mas promoter, the maximum expression level was $74 \mu \mathrm{g} / \mathrm{g}$ FW [174].

Grains are a further option for the expression of candidate vaccine antigens. They have long stability of expressed recombinant proteins with low water content [212]. In maize seed, the maximum expression has been reported at $0.51 \%$ of total soluble protein (approximately $80 \mu \mathrm{g} / \mathrm{g} F W$ ). This level of expression was achieved using a barley alpha amylase signal sequence-fused S-HBsAg gene with a $3 \times$ globulin1 promoter [168]. All of the results suggest that the expression levels of HBsAg are highly variable and depend on plant species, tissue types and culture conditions.

The major recombinant hepatitis B vaccines contain S-HBsAg; therefore, the expression of this protein has been the focus in plants. The proteins preS2-S, M-HBsAg, and preS1-preS2-S, L-HBsAg, have been much less studied than S-HBsAg. M-HBsAg and L-HBsAg have been transformed into potato, tomato, and tobacco (Table 3). Although the expression was optimized using suitable promoters, leader sequences and targeting signals, the expression levels of M-/L-HBsAg were lower than for S-HBsAg. However, HBcAg induces a heightened immune response $[213,214]$ and spontaneously assembles into capsid-like particles [215]. For these reasons, efforts devoted to the production of an anti-HBV vaccine have focused on HBcAg in the last few years. Especially, HBcAg has been abundantly produced using transient expression systems mediated by ICON binary vectors [208] or viral vector systems [209] (Table 3).

\section{Breakthroughs Regarding the Weak Points of Plant-Derived HBV Antigens as Injected Vaccines}

Transgenic tobacco plants-derived HBsAg was antigenically and physically similar to the human serum and recombinant yeast derived-HBsAg particles [163]. To analyze the immunological response in vivo, tobacco-expressed HBsAg was purified and injected into BALB/c mice. The anti-HepB response to the tobacco-derived HBsAg was qualitatively similar to the response obtained by immunizing mice with commercialized yeast-derived HBsAg vaccine [175]. These results showed a possibility of developing injected vaccines using plant-expressed HBsAg.

Due to differences of the manufacturing processes between companies, the amount of HBsAg protein per dose differs among the various HBV vaccine products [216]. For this reason, there is no international standard for the HBsAg protein quantity in vaccines, but there is a standard based on protective efficacy of vaccination related to the anti-HepB antibodies induction. An anti-HBsAg of 
$\geq 10 \mathrm{mIU} / \mathrm{mL}$ measured 1-3 months after the last dose of the vaccine are considered to be immune to HepB. Although no international standard of antigen concentration is defined, considering the feasibility and cost-effectiveness of the injected vaccine, the concentration of antigen should be over $40 \mu \mathrm{g} / \mathrm{mL}$ [217].

Despite many attempts to increase HBsAg expression in transgenic plants, the expression level remains too low for use as an injected vaccine. The currently used HBV vaccine contains HBsAg and is produced by yeast cells. The yeast-derived HBV vaccine can be supplied inexpensively ( $\$ 1-20$ per single dose [218]); therefore, it is difficult for plant-derived vaccines to have a competitive price. However, plant suspension cultures may be used as an alternative to yeast to produce antigens for purification. Expression levels have approached $74 \mu \mathrm{g} / \mathrm{g}$ FW $(22 \mathrm{mg} / \mathrm{L}$ culture medium) in transgenic soybean culture [174]. Although the expression level $(8 \mu \mathrm{g} / \mathrm{g} \mathrm{FW})$ was lower in transgenic tobacco cell suspension culture than in soybean [174], the former has been used to secrete HBsAg into the culture medium, with a six-fold increase in secretion in response to jasmonic acid or salicylic acid treatment during cell culture, and the amount of antigen secreted was $180 \mu \mathrm{g} / \mathrm{L}$ medium [170].

Another breakthrough regarding expression problems was achieved through the utilization of virus-based transient expression systems for the robust production of $\mathrm{HBV}$ antigens, such as S-HBsAg and HBcAg, with yields as high as $2 \mathrm{mg} / \mathrm{g}$ FW [208,209,211]. Tobacco-derived proteins showing the maximum anti-HBsAg antibody titer of $1165 \mathrm{mIU}$ in immunized mice serum [211] are preferred the application of injection after purification process, rather than oral administration in order to remove many toxic alkaloids and phenolic substances which have a tobacco plant [219]. However, improvements of several orders of magnitude are still needed for plant cell culture systems to be competitive, particularly given the slow growth rates of plant cells compared with yeast.

In transgenic suspension cell culture, the formation of VLPs by HBV antigens made it possible to exploit relatively inexpensive protein purification techniques, such as the sucrose gradient $[174,182,184]$ or cesium chloride gradient ultracentrifugation [173]. The highest expressed soybean cell culture was used for antigen purification, and the antigen was suitable for injection [174], but the yield remained unsatisfactory and was not cost-effective.

\section{Breakthroughs Regarding the Weak Points of Plant-Derived HBV Antigens as Oral Vaccines}

The biggest advantage of edible plant-derived vaccines is their easy application to oral delivery. The benefits of plant-derived edible vaccines are as follows: (1) during oral delivery, plant-derived vaccines are protected in the stomach by plant cell wall and slow release in the gut; (2) the plant tissue expressing antigen may be used as raw or dried food; (3) capsules can also be made from partially or fully purified vaccine proteins; (4) no need for cold chain systems for storage and delivery of the plant tissues or extracts; and (5) the plant-derived vaccines are cost efficient compared with traditional vaccines.

Edible plant-derived HBV antigens have been administered by oral injection or feeding in mice with/without adjuvants $[41,165-167,193]$. An oral vaccine candidate has also been administered to human volunteers in small-scale clinical trials without adjuvants. The first trial was administered to three human volunteers in row lettuce leaves in two doses (0.5-1 $\mu$ g of S-HBsAg/dose) without the use of an adjuvant. All volunteers responded, with two of them having serum responses in excess of the protective minimum level ( $10 \mathrm{mIU} / \mathrm{mL}$ of serum). However, the antibody levels declined rapidly $[187,220]$. In the second trial, previously vaccinated human volunteers were fed two or three doses of $100 \mathrm{~g}$ of raw potato tubers (approximately $1 \mathrm{mg}$ of the S-HBsAg/dose). More than half of the subjects showed increased antibody titers [221]. The animal experiments and trials showed the potential for plant-derived HBV antigens to be used as an oral vaccine for the prevention of HBV, but there remain many problems to be solved for practical application, such as the administration of bulky plant material, declining long-term responses, individual differences in the immune response and the difficulty of defining the antigen dose [222]. 
The expression level of plant-derived HBV antigen is only $1 / 20-1 / 25$ of the expression of yeast-derived HBV antigen; however, the expression yield and plant production scale are still increasing [223,224]. Tomato is possible intake without any processing or cooking. Therefore, tomato fruit is a very attractive crop to develop an oral vaccine. According to the study to date, the expression level of HBV antigen was very low as $10 \mathrm{ng} / \mathrm{g}$ FW (Table 3). The maximum titers of anti-HBsAg antibody in serum is $300 \mathrm{mIU}$ using oral application. This antibody yield was high compared to the expression level of HBV antigen in tomato fruits [225]. HBV antigen expression in maize produced much higher levels of antigen, and the palatability and digestibility were better than for potato. That is, cereal crops can easily transport or storage in dry state. In addition, the maize system induced a strong immune response with $4632 \mathrm{mIU}$ of maximum titer by both injection and oral administration $[193,194]$. This result suggests the possibility of providing a raw material for thermostable formulation at $\$ 0.01$ per dose [193]. Plant components such as saponin, flavonoids, and plant oils also function as adjuvants [226-228] and help maintain the immune response in the long term [195].

The lyophilization method is an excellent way to increase the stability and shelf life of the plant-derived vaccines. In the previous study, the storage stability of lyophilized powder form was limited at $4{ }^{\circ} \mathrm{C}$ [189]. In a recent study, successful long-term storage at $37{ }^{\circ} \mathrm{C}$ was achieved though improvements in the process [229]. It is easier to control the concentration and standardize antigen doses and process the antigen into a tablet or capsule form using a powdered tissue instead of freeze-drying [188].

\section{Conclusions}

Despite over 20 years of effort, no commercial plant-based anti-HBV vaccine has been developed. To commercialize a plant-derived HBV vaccine, several points should be considered. First, the greatest barrier is the low expression levels of HBV antigen in plants; however, expression yield and plant production scale can still be increased using plant expression vector optimization, which should be focused on the target plant. The process can also be more competitive by improving the plant-derived antigen to increase the immune response to the vaccine. Second, an HBV antigen expressed in an edible plant has the advantage of being usable as an oral vaccine without processing. It is first necessary to analyze the characteristics of the target plants and the expressed protein for the development of an oral vaccine because plant components, secondary metabolites and foreign protein expression characteristics vary with plant species. To obtain feasible and cost-effective vaccines, the target plants for edible vaccines should have a long shelf life, be heat stable and be edible as a raw material. Candidate grain crops are maize and rice; candidate vegetative crops are tomato and banana. Third, consideration should be made of the public's acceptance of GM crops, especially plant-derived edible vaccines. For injected vaccine development, the most cost-effective method is a suspension culture in a closed environment, according to the regulations of good manufacturing practice. Further safety of plant-derived vaccines can be obtained by following the same regulations established for traditional vaccines. In addition, for oral vaccines produced from GM crops, environmental risk assessment and human risk assessment should be performed. For these reasons, plant-derived oral vaccines cannot be called cost efficient compared with traditional vaccines, and the current concern over the use of GM plants is now affecting research in this field.

Acknowledgments: This work was partially supported by a grant from the Next-Generation BioGreen 21 Program (Rural Development Administration, \#PJ011246) (Young Hee Joung) and IPET research funding program (MAFRA, \#312037052SB) (Hyun-Soon Kim) of Korea.

Author Contributions: Young Hee Joung and Hyun-Soon Kim developed the concept and drafted the manuscript; Se Hee Park, Ki-Beom Moon and Hye-Sun Cho searched for references and finalized the tables; Jae-Heung Jeon revised the manuscript critically; All authors have read and approved the final version of the manuscript.

Conflicts of Interest: The authors declare no conflict of interest. 


\section{References}

1. World Health Organization (WHO). Hepatitis B Fact Sheet, July 2016. Available online: http://www.who. int.mediacentre/factsheets/fs204/en/ (accessed on 3 August 2016).

2. Miller, R.H.; Kaneko, S.; Chung, C.T.; Girones, R.; Purcell, R.H. Compact organization of the hepatitis B virus genome. Hepatotlogy 1989, 9, 322-327. [CrossRef]

3. Wen, Y.M. Structural and functional analysis of full-length hepatitis B virus genomes in patients: Implications in pathogenesis. J. Gastroenterol. Hepatol. 2004, 19, 485-498. [CrossRef] [PubMed]

4. Caligiuri, P.; Cerruti, R.; Icardi, G.; Bruzzone, B. Overview of hepatitis B virus mutations and their implications in the management of infection. World J. Gastroenterol. 2016, 22, 145-154. [CrossRef] [PubMed]

5. Krugman, S. The newly licensed hepatitis B vaccine: Characterics and indications for use. J. Am. Med. Assoc. 1982, 247, 2012-2015. [CrossRef]

6. McAleer, W.J.; Buynak, E.B.; Maigetter, R.Z.; Miller, W.J.; Hilleman, M.R. Human hepatitis B vaccine from recombinant yeast. Nature 1984, 307, 178-180. [CrossRef] [PubMed]

7. Zuckerman, J.N.; Zuckerman, A.J. Recombinant hepatitis B triple antigen vaccine: Hepacare. Expert Rev. Vaccines 2002, 1, 141-144. [CrossRef] [PubMed]

8. Rendi-Wagner, P.; Shouval, D.; Genton, B.; Lurie, Y.; Rumke, H.; Boland, G.; Cerny, A.; Heim, M.; Bach, D.; Schroeder, M.; et al. Comparative immunogenicity of a PreS/S hepatitis B vaccine in non- and low responders to conventional vaccine. Vaccine 2006, 24, 2781-2789. [CrossRef] [PubMed]

9. Bruss, V. Hepatitis B virus morphogenesis. World J. Gasteroenterol. 2007, 13, 65-73. [CrossRef]

10. Couillin, I.; Pol, S.; Mancini, M.; Driss, F.; Brechot, C.; Tiollais, P.; Michel, M.L. Specific vaccine therapy in chronic hepatitis B: Induction of T cell proliferative responses specific for envelope antigens. J. Infect. Dis. 1999, 180, 15-26. [CrossRef] [PubMed]

11. Böcher, W.O.; Dekel, B.; Schwerin, W.; Geissler, M.; Hoffmann, S.; Rohwer, A.; Arditti, F.; Cooper, A.; Bernhard, H.; Berrebi, A.; et al. Induction of strong hepatitis B virus (HBV) specific T helper cell and cytotoxic T lymphocyte responses by therapeutic vaccination in the trimera mouse model of chronic HBV infection. Eur. J. Immunol. 2001, 31, 2071-2079. [CrossRef]

12. Chen, X.; Li, M.; Le, X.; Ma, W.; Zhou, B. Recombinant hepatitis B core antigen carrying preS1 epitopes induce immune response against chronic HBV infection. Vaccine 2004, 22, 439-446. [CrossRef] [PubMed]

13. Daniell, H.; Streatfield, S.J.; Wycoff, K. Medical molecular farming: Production of antibodies, biopharmaceuticals and edible vaccines in plants. Trends Plant Sci. 2001, 6, 219-226. [CrossRef]

14. Frey, J. Biological safety concepts of genetically modified live bacterial vaccines. Vaccine 2006, 25, 5598-5605. [CrossRef] [PubMed]

15. Jamal, A.; Ko, K.; Kim, H.S.; Choo, Y.K.; Joung, H.; Ko, K. Role of genetic factors and environmental conditions in recombinant protein production for molecular farming. Biotechnol. Adv. 2009, 27, 914-923. [CrossRef] [PubMed]

16. Thomas, D.R.; Penney, C.; Majumder, A.; Walmsley, A.M. Evolution of plant-made pharmaceuticals. Int. J. Mol. Sci. 2011, 12, 3220-3236. [CrossRef] [PubMed]

17. Perez-Martinez, A.S.; Acevedo-Padilla, S.A.; Bibbins-Martinez, M.; Galvan-Alonso, J.; Rosales-Mendoza, S. A perspective on the use of Pleurotus for the development of convenient fungi-made oral subunit vaccines. Vaccine 2015, 33, 25-33. [CrossRef] [PubMed]

18. Rosales-Mendoza, S.; Gonzalez, J.A.S. Immunological aspects of using plant cells as delivery vehicles for oral vaccines. Expert Rev. Vaccines 2014, 13, 737-749. [CrossRef] [PubMed]

19. Merlin, M.; Gecchele, E.; Capaldi, S.; Pezzotti, M.; Avesani, L. Comparative evaluation of recombinant protein production in different biofactories: The green perspective. BioMed Res. Int. 2014. [CrossRef] [PubMed]

20. Rosalez-Mendoza, S.; Tello-Olea, M.A. Carrot cells: A pioneering platform for biopharmaceuticals production. Mol. Biotechnol. 2015, 57, 219-232. [CrossRef] [PubMed]

21. Yao, J.; Weng, Y.; Dickey, A.; Wang, K.Y. Plants as factories for human pharmaceuticals: Applications and challenges. Int. J. Mol. Sci. 2015, 16, 28549-28565. [CrossRef] [PubMed]

22. Medicago Inc. Pipeline Progress. Available online: http://medicago.com/pipeline-progress/ (accessed on 25 August 2016).

23. Marsian, J.; Lomonossoff, G.P. Molecular pharming-VLPs made in plants. Curr. Opin. Biotechnol. 2016, 37, 201-206. [CrossRef] [PubMed] 
24. Young, K.R.; Arthus-Cartier, G.; Yam, K.K.; Lavoie, P.O.; Landry, N.; D'Aoust, M.A.; Vezina, L.P.; Couture, M.M.J.; Ward, B.J. Generation and characterization of a trackable plant-made influenza H5 virus-like particle containing enhanced green fluorescent protein. FASEB J. 2015, 29, 3817-3827. [CrossRef] [PubMed]

25. Biemelt, S.; Sonnewald, U.; Galmbacher, P.; Willmitzer, L.; Müller, M. Production of human papillomavirus type 16 virus-like particles in transgenic plants. J. Virol. 2003, 77, 9211-9220. [CrossRef] [PubMed]

26. Greco, R.; Michel, M.; Guetard, D.; Cervantes-Gonzalez, M.; Pelucchi, N.; Wain-Hobson, S.; Sala, F.; Sala, M. Production of recombinant HIV-1/HBV virus-like particles in Nicotiana tabacum and Arabidopsis thaliana plants for a bivalent plant-based vaccine. Vaccine 2007, 25, 8228-8240. [CrossRef] [PubMed]

27. Kessans, S.A.; Frater, J.; Matoba, N.; Mor, T. Plant expression of chimeric Gag/gp41 virus-like particles as a mucosally-targeted subunit vaccine against HIV-1. Retrovirology 2009, 6, 15. [CrossRef]

28. Santi, L.; Batchelor, L.; Huang, Z.; Hjelm, B.; Kilbourne, J.; Arntzen, C.; Chen, Q.; Mason, H.S. An efficient plant viral expression system generating orally immunogenic Norwalk virus-like particles. Vaccine 2008, 26, 1846-1854. [CrossRef] [PubMed]

29. Marillonnet, S.; Giritch, A.; Gils, M.; Kandzia, R.; Klimyuk, V.; Gleba, Y. In planta engineering of viral RNA replicons: Efficient assembly by recombination of DNA modules delivered by Agrobacterium. Proc. Natl. Acad. Sci. USA 2004, 101, 6852-6857. [CrossRef] [PubMed]

30. Huang, Z.; LePore, K.; Elkin, G.; Thanaval, Y.; Mason, H.S. High-yield rapid production of hepatitis B surface antigen in plant leaf by a viral expression system. Plant Biotechnol. J. 2008, 6, 202-209. [CrossRef]

31. Salazar-González, J.A.; Bañuelos-Hernández, B.; Rosales-Mendoza, S. Current status of viral expression systems in plants and perspectives for oral vaccines development. Plant Mol. Biol. 2015, 87, $203-217$. [CrossRef] [PubMed]

32. Salazar-Gonzáleza, J.A.; Angulob, C.; Rosales-Mendozaa, S. Chikungunya virus vaccines: Current strategies and prospects for developing plant-made vaccines. Vaccine 2015, 33, 3650-3658. [CrossRef] [PubMed]

33. Sánchez-Rodríguez, S.P.; Münch-Anguiano, L.; Bustos-Jaimes, I. Advances in the development of virus-like particles as tools in medicine and nanoscience. Curr. Chem. Biol. 2010, 4, 231-243.

34. Zeltins, A. Construction and characterization of virus-like particles: A review. Mol. Biotechnol. 2013, 53, 92-107. [CrossRef] [PubMed]

35. Moon, K.B.; Lee, J.; Kang, S.; Kim, M.; Mason, H.S.; Jeon, J.H.; Kim, H.S. Overexpression and self-assembly of virus-like particles in Nicotiana benthamiana by a single-vector DNA replicon system. Appl. Microbiol. Biotechnol. 2014, 98, 8281-8290. [CrossRef] [PubMed]

36. Yan, D.; Wei, Y.Q.; Guo, H.C.; Sun, S.Q. The application of virus-like particles as vaccines and biological vehicles. Appl. Microbiol. Biotechnol. 2015, 99, 10415-10432. [CrossRef] [PubMed]

37. Paul, M.; Ma, J.K. Plant-made pharmaceuticals: Leading products and production platforms. Biotechnol. Appl. Biochem. 2011, 58, 58-67. [CrossRef] [PubMed]

38. Streatfield, S.J. Approaches to achieve high-level heterologous protein production in plants. Plant Biotechnol. J. 2007, 5, 2-15. [CrossRef] [PubMed]

39. Fahad, S.; Faheem, A.K.; Pandupuspitasari, N.S.; Ahmed, M.M.; Liao, Y.C.; Waheed, M.T.; Sameeullah, M.; Darkhshan, H.S.; Saud, S.; Hassan, S.; et al. Recent developments in therapeutic protein expression technologies in plants. Biotechnol. Lett. 2015, 37, 265-279. [CrossRef] [PubMed]

40. Waheed, M.T.; Ismail, H.; Gottschamel, J.; Mirza, B.; Lossl, A.G. Plastids: The green frontiers for vaccine production. Front. Plant Sci. 2015, 6, 1005. [CrossRef] [PubMed]

41. Thanavala, Y.; Mahoney, M.; Pal, S.; Scott, A.; Richter, L.; Natarajan, N.; Goodwin, P.; Arntzen, C.; Mason, H.S. Immunogenicity in humans of an edible vaccine for hepatitis B. Proc. Natl. Acad. Sci. USA 2005, 102, 3378-3382. [CrossRef] [PubMed]

42. Zhang, X.; Buehner, N.A.; Hutson, A.M.; Estes, M.K.; Mason, H.S. Tomato is a highly effective vehicle for expression and oral immunization with Norwalk virus capsid protein. Plant Biotechnol. J. 2006, 4, 419-432. [CrossRef] [PubMed]

43. Santi, L.; Giritch, A.; Roy, C.J.; Marillonnet, S.; Klimyuk, V.; Gleba, Y.; Webb, R.; Arntzen, C.; Mason, H.S. Protection conferred by recombinant Yersinia pestis antigens produced by a rapid and highly scalable plant expression system. Proc. Natl. Acad. Sci. USA 2006, 103, 861-866. [CrossRef] [PubMed]

44. Guerrero-Andrade, O.; Loza-Rubio, E.; Olivera-Flores, T.; Fehérvári-Bone, T.; Gómez-Lim, M.A. Expression of the Newcastle disease virus fusion protein in transgenic maize and immunological studies. Transgenic Res. 2006, 15, 455-463. [CrossRef] [PubMed] 
45. Li, J.T.; Fei, L.; Mou, Z.R.; Wei, J.; Tang, Y.; He, H.Y.; Wang, L.; Wu, Y.Z. Immunogenicity of a plant-derived edible rotavirus subunit vaccine transformed over fifty generations. Virology 2006, 356, 171-178. [CrossRef] [PubMed]

46. Jiang, X.L.; He, Z.M.; Peng, Z.Q.; Qi, Y.; Chen, Q.; Yu, S.Y. Cholera toxin B protein in transgenic tomato fruit induces systemic immune response in mice. Transgenic Res. 2007, 16, 169-175. [CrossRef] [PubMed]

47. Moravec, T.; Schmidt, M.A.; Herman, E.M.; Woodford-Thomas, T. Production of Escherichia coli heat labile toxin (LT) B subunit in soybean seed and analysis of its immunogenicity as an oral vaccine. Vaccine 2007, 25, 1647-1657. [CrossRef] [PubMed]

48. Nochi, T.; Takagi, H.; Yuki, Y.; Yang, L.; Masumura, T.; Mejima, M.; Nakanishi, U.; Matsumura, A.; Uozumi, A.; Hiroi, T.; et al. Rice-based mucosal vaccine as a global strategy for cold-chain-and needle-free vaccination. Proc. Natl. Acad. Sci. USA 2007, 104, 10986-10991. [CrossRef] [PubMed]

49. Rosales-Mendoza, S.; Soria-Guerra, R.E.; Lopez-Revilla, R.; Moreno-Fierros, L.; Alpuche-Solis, A.G. Ingestion of transgenic carrots expressing the Escherichia coli heat-labile enterotoxin B subunit protects mice against cholera toxin challenge. Plant Cell Rep. 2008, 27, 79-84. [CrossRef] [PubMed]

50. Lugade, A.A.; Kalathil, S.; Heald, J.L.; Thanavala, Y. Transgenic plant-based oral vaccines. Immunol. Investig. 2010, 39, 468-482. [CrossRef] [PubMed]

51. Daniell, H.; Chebolu, S.; Kumar, S.; Singleton, M.; Falconer, R. Chloroplast-derived vaccine antigens and other therapeutic proteins. Vaccine 2005, 23, 1779-1783. [CrossRef] [PubMed]

52. Oey, M.; Lohse, M.; Kreikemeyer, B.; Bock, R. Exhaustion of the chloroplast protein synthesis capacity by massive expression of a highly stable protein antibiotic. Plant J. 2009, 57, 436-445. [CrossRef] [PubMed]

53. Ruhlman, T.; Verma, D.; Samson, N.; Daniell, H. The role of heterologous chloroplast sequence elements in transgene integration and expression. Plant Physiol. 2010, 152, 2088-2104. [CrossRef] [PubMed]

54. Rybicki, E.P. Plant-produced vaccines: Promise and reality. Drug Discov. Today 2009, 14, 16-24. [CrossRef] [PubMed]

55. Rybicki, E.P. Plant-made vaccines for humans and animals. Plant Biotechnol. J. 2010, 8, 620-637. [CrossRef] [PubMed]

56. Lossl, A.G.; Waheed, M.T. Chloroplast-derived vaccines against human diseases: Achievements, challenges and scopes. Plant Biotechnol. J. 2011, 9, 527-539. [CrossRef] [PubMed]

57. Pogue, G.P.; Vojdani, F.; Palmer, K.E.; Hiatt, E.; Hume, S.; Phelps, J.; Long, L.; Bohorova, N.; Kim, D.; Pauly, M.; et al. Production of pharmaceutical-grade recombinant aprotinin and a monoclonal antibody product using plant-based transient expression systems. Plant Biotechnol. J. 2010, 8, 638-654. [CrossRef] [PubMed]

58. Komarova, T.V.; Baschieri, S.; Donini, M.; Marusic, C.; Benvenuto, E.; Dorokhov, Y.L. Transient expression systems for plant-derived biopharmaceuticals. Expert Rev. Vaccines 2010, 9, 859-876. [CrossRef] [PubMed]

59. Spiegel, H.; Boes, A.; Voepel, N.; Beiss, V.; Edgue, G.; Rademacher, T.; Sack, M.; Schillberg, S.; Reimann, A.; Fischer, R. Application of a scalable plant transient gene expression platform for malaria vaccine development. Front. Plant Sci. 2015, 6, 1169. [CrossRef] [PubMed]

60. Marin Viegas, V.S.; Acevedo, G.R.; Bayardo, M.P.; Chirdo, F.G.; Petruccelli, S. Production of the main celiac disease autoantigen by transient expression in Nicotiana benthamiana. Front. Plant Sci. 2015, 6, 1067. [CrossRef] [PubMed]

61. Fischer, R.; Vasilev, N.; Twyman, R.M.; Schillberg, S. High-value products from plants: The challenges of process optimization. Curr. Opin. Biotechnol. 2015, 32, 156-162. [CrossRef] [PubMed]

62. Hiatt, A.; Pauly, M. Monoclonal antibodies from plants: A new speed record. Proc. Natl. Acad. Sci. USA 2006, 103, 14645-14646. [CrossRef] [PubMed]

63. Nausch, H.; Mikschofsky, H.; Koslowski, R.; Meyer, U.; Broer, I.; Huckauf, J. High-level transient expression of ER-targeted human interleukin 6 in Nicotiana benthamiana. PLoS ONE 2012, 7, e48938. [CrossRef] [PubMed]

64. Alvesani, L.; Merlin, M.; Gecchele, E.; Capaldi, S.; Brozzetti, A.; Falorni, A.; Pezzotti, M. Comparative analysis of different biofactories for the production of a major diabetes autoantigen. Transgenic Res. 2013, 23, 281-291. [CrossRef] [PubMed]

65. Beiss, V.; Spiegel, H.; Boes, A.; Scheuermayer, M.; Reimann, A.; Schillberg, S.; Fischer, R. Plant expression and characterization of the transmission-blocking vaccine candidate PfGAP50. BMC Biotechnol. 2015, 15, 108. [CrossRef] [PubMed] 
66. Beiss, V.; Spiegel, H.; Boes, A.; Kapelski, S.; Scheuermayer, M.; Edgue, G.; Sack, M.; Fendel, R.; Reimann, A.; Schillberg, S. Heat-precipitation allows the efficient purification of a functional plant-derived malaria transmission-blocking vaccine candidate fusion protein. Biotechnol. Bioeng. 2015, 112, 1297-1305. [CrossRef] [PubMed]

67. Voepel, N.; Boes, A.; Edgue, G.; Beiss, V.; Kapelski, S.; Reimann, A.; Schillberg, S.; Pradel, G.; Fendel, R.; Scheuermayer, M. Malaria vaccine candidate antigen targeting the pre-erythrocytic stage of Plasmodium falciparum produced at high level in plants. Biotechnol. J. 2014, 9, 1435-1445. [CrossRef] [PubMed]

68. Feller, T.; Thom, P.; Koch, N.; Spiegel, H.; Addai-Mensah, O.; Fischer, R.; Reimann, A.; Pradel, G.; Fendel, R.; Schillberg, S. Plant-based production of recombinant Plasmodium surface protein Pf38 and evaluation of its potential as a vaccine candidate. PLoS ONE 2013, 8, e79920. [CrossRef] [PubMed]

69. Jones, R.M.; Chichester, J.A.; Mett, V.; Jaje, J.; Tottey, S.; Manceva, S.; Casta, L.J.; Gibbs, S.K.; Musiychuk, K.; Shamloul, M. A plant-produced Pfs25 VLP malaria vaccine candidate induces persistent transmission blocking antibodies against Plasmodium falciparum in immunized mice. PLoS ONE 2013, 8, e79538. [CrossRef] [PubMed]

70. Kantor, M.; Sestras, R.; Chowdhury, K. Transgenic tomato plants expressing the antigen gene PfCP-2.9 of Plasmodium falciparum. Pesq. Agropec. Bras. 2013, 48, 73-79. [CrossRef]

71. Ma, C.; Wang, L.; Webster, D.E.; Campbell, A.E.; Coppel, R.L. Production, characterisation and immunogenicity of a plant-made Plasmodium antigen the $19 \mathrm{kDa}$ C-terminal fragment of Plasmodium yoelii merozoite surface protein 1. Appl. Microbiol. Biotechnol. 2012, 94, 151-161. [CrossRef] [PubMed]

72. Farrance, C.E.; Rhee, A.; Jones, R.M.; Musiychuk, K.; Shamloul, M.; Sharma, S.; Mett, V.; Chichester, J.A.; Streatfield, S.J.; Roeffen, W. A plant-produced Pfs230 vaccine candidate blocks transmission of Plasmodium falciparum. Clin. Vaccine Immunol. 2011, 18, 1351-1357. [CrossRef] [PubMed]

73. Webster, D.E.; Wang, L.; Mulcair, M.; Ma, C.; Santi, L.; Mason, H.S.; Wesselingh, S.L.; Coppel, R.L. Production and characterization of an orally immunogenic Plasmodium antigen in plants using a virus-based expression system. Plant Biotechnol. J. 2009, 7, 846-855. [CrossRef] [PubMed]

74. Vamvaka, E.; Twyman, R.M.; Murad, A.M.; Melnik, S.; Teh, A.Y.H.; Arcalis, E.; Altmann, F.; Stoger, E.; Rech, E.; Ma, J.K.C.; et al. Rice endosperm produces an underglycosylated and potent form of the HIV-neutralizing monoclonal antibody 2G12. Plant Biotechnol. J. 2016, 14, 97-108. [CrossRef] [PubMed]

75. Rubio-Infante, N.; Govea-Alonso, D.O.; Romero-Maldonado, A.; García-Hernández, A.L.; Ilhuicatzi-Alvarado, D.; Salazar-González, J.A.; Korban, S.S.; Rosales-Mendoza, S.; Moreno-Fierros, L. A plant-derived multi-HIV antigen induces broad immune responses in orally immunized mice. Mol. Biotechnol. 2015, 57, 662-674. [CrossRef] [PubMed]

76. Lindh, I.; Bråve, A.; Hallengärd, D.; Hadad, R.; Kalbina, I.; Strid, Å.; Andersson, S. Oral delivery of plant-derived HIV-1 p24 antigen in low doses shows a superior priming effect in mice compared to high doses. Vaccine 2014, 32, 2288-2293. [CrossRef] [PubMed]

77. Rosales-Mendoza, S.; Rubio-Infante, N.; Monreal-Escalante, E.; Govea-Alonso, D.O.; García-Hernández, A.L.; Salazar-González, J.A.; González-Ortega, O.; Paz-Maldonado, L.T.; Moreno-Fierros, L. Chloroplast expression of an HIV envelop-derived multiepitope protein: Towards a multivalent plant-based vaccine. Plant Cell Tissue Organ Cult. 2014, 116, 111-123. [CrossRef]

78. Matoba, N.; Cherni, I.; Kessans, S.; Frater, J.; Preston, K.; Bomsel, M.; Mor, T. Biochemical and immunological characterization of the plant-derived candidate HIV-1 mucosal vaccine CTB-MPR. Retrovirology 2009, 6, 182. [CrossRef]

79. Barbante, A.; Irons, S.; Hawes, C.; Frigerio, L.; Vitale, A.; Pedrazzini, E. Anchorage to the cytosolic face of the endoplasmic reticulum membrane: A new strategy to stabilize a cytosolic recombinant antigen in plants. Plant Biotechnol. J. 2008, 6, 560-575. [CrossRef] [PubMed]

80. Meyers, A.; Chakauya, E.; Shephard, E.; Tanzer, F.L.; Maclean, J.; Lynch, A.; Williamson, A.L.; Rybicki, E.P. Expression of HIV-1 antigens in plants as potential subunit vaccines. BMC Biotechnol. 2008, 8, 53. [CrossRef] [PubMed]

81. Mardanova, E.S.; Kotlyarov, R.Y.; Kuprianov, V.V.; Stepanova, L.A.; Tsybalova, L.M.; Lomonosoff, G.P.; Ravin, N.V. Rapid high-yield expression of a candidate influenza vaccine based on the ectodomain of M2 protein linked to flagellin in plants using viral vectors. BMC Biotechnol. 2015, 15, 42. [CrossRef] [PubMed] 
82. Firsov, A.; Tarasenko, I.; Mitiouchkina, T.; Ismailova, N.; Shaloiko, L.; Vainstein, A.; Dolgov, S. High-yield expression of M2e peptide of avian influenza virus H5N1 in transgenic duckweed plants. Mol. Biotechnol. 2015, 57, 653-661. [CrossRef] [PubMed]

83. Lee, G.; Na, Y.J.; Yang, B.G.; Choi, J.P.; Seo, Y.B.; Hong, C.P.; Yun, C.H.; Kim, D.H.; Sohn, E.J.; Kim, J.H. Oral immunization of haemaggulutinin $\mathrm{H} 5$ expressed in plant endoplasmic reticulum with adjuvant saponin protects mice against highly pathogenic avian influenza A virus infection. Plant Biotechnol. J. 2015, 13, 62-72. [CrossRef] [PubMed]

84. Major, D.; Chichester, J.A.; Pathirana, R.D.; Guilfoyle, K.; Shoji, Y.; Guzman, C.A.; Yusibov, V.; Cox, R.J. Intranasal vaccination with a plant-derived H5 HA vaccine protects mice and ferrets against highly pathogenic avian influenza virus challenge. Hum. Vaccines Immunother. 2015, 11, 1235-1243. [CrossRef] [PubMed]

85. Le Mauff, F.; Mercier, G.; Chan, P.; Burel, C.; Vaudry, D.; Bardor, M.; Vézina, L.P.; Couture, M.; Lerouge, P.; Landry, N. Biochemical composition of haemagglutinin-based influenza virus-like particle vaccine produced by transient expression in tobacco plants. Plant Biotechnol. J. 2015, 13, 717-725. [CrossRef] [PubMed]

86. Pillet, S.; Racine, T.; Nfon, C.; di Lenardo, T.; Babiuk, S.; Ward, B.; Kobinger, G.; Landry, N. Plant-derived H7 VLP vaccine elicits protective immune response against H7N9 influenza virus in mice and ferrets. Vaccine 2015, 33, 6282-6289. [CrossRef] [PubMed]

87. Cummings, J.F.; Guerrero, M.L.; Moon, J.E.; Waterman, P.; Nielsen, R.K.; Jefferson, S.; Gross, F.L.; Hancock, K.; Katz, J.M.; Yusibov, V. Safety and immunogenicity of a plant-produced recombinant monomer hemagglutinin-based influenza vaccine derived from influenza A (H1N1) pdm09 virus: A Phase I dose-escalation study in healthy adults. Vaccine 2014, 32, 2251-2259. [CrossRef] [PubMed]

88. Ward, B.J.; Landry, N.; Trépanier, S.; Mercier, G.; Dargis, M.; Couture, M.; D’Aoust, M.A.; Vézina, L.P. Human antibody response to $\mathrm{N}$-glycans present on plant-made influenza virus-like particle (VLP) vaccines. Vaccine 2014, 32, 6098-6106. [CrossRef] [PubMed]

89. Shoji, Y.; Farrance, C.E.; Bautista, J.; Bi, H.; Musiychuk, K.; Horsey, A.; Park, H.; Jaje, J.; Green, B.J.; Shamloul, M. A plant-based system for rapid production of influenza vaccine antigens. Influenza Other Respir. Viruses 2012, 6, 204-210. [CrossRef] [PubMed]

90. Jul-Larsen, Å.; Madhun, A.S.; Brokstad, K.A.; Montomoli, E.; Yusibov, V.; Cox, R.J. The human potential of a recombinant pandemic influenza vaccine produced in tobacco plants. Hum. Vaccines Immunother. 2012, 8 , 653-661. [CrossRef] [PubMed]

91. Mortimer, E.; Maclean, J.M.; Mbewana, S.; Buys, A.; Williamson, A.L.; Hitzeroth, I.I.; Rybicki, E.P. Setting up a platform for plant-based influenza virus vaccine production in South Africa. BMC Biotechnol. 2012, 12, 14. [CrossRef] [PubMed]

92. Iyer, V.; Liyanage, M.R.; Shoji, Y.; Chichester, J.A.; Jones, R.M.; Yusibov, V.; Joshi, S.B.; Middaugh, C.R. Formulation development of a plant-derived H1N1 influenza vaccine containing purified recombinant hemagglutinin antigen. Hum. Vaccines Immunother. 2012, 8, 453-464. [CrossRef] [PubMed]

93. Ravin, N.; Kotlyarov, R.; Mardanova, E.; Kuprianov, V.; Migunov, A.; Stepanova, L.; Tsybalova, L.; Kiselev, O.; Skryabin, K. Plant-produced recombinant influenza vaccine based on virus-like HBc particles carrying an extracellular domain of M2 protein. Biochemistry 2012, 77, 33-40. [CrossRef] [PubMed]

94. Landry, N.; Ward, B.J.; Trépanier, S.; Montomoli, E.; Dargis, M.; Lapini, G.; Vézina, L.-P. Preclinical and clinical development of plant-made virus-like particle vaccine against avian H5N1 influenza. PLoS ONE 2010, 5, e15559. [CrossRef] [PubMed]

95. Mett, V.; Musiychuk, K.; Bi, H.; Farrance, C.E.; Horsey, A.; Ugulava, N.; Shoji, Y.; de La Rosa, P.; Palmer, G.A.; Rabindran, S. A plant-produced influenza subunit vaccine protects ferrets against virus challenge. Influenza Other Respir. Viruses 2008, 2, 33-40. [CrossRef] [PubMed]

96. Shoji, Y.; Chichester, J.A.; Bi, H.; Musiychuk, K.; de la Rosa, P.; Goldschmidt, L.; Horsey, A.; Ugulava, N.; Palmer, G.A.; Mett, V.; et al. Plant-expressed HA as a seasonal influenza vaccine candidate. Vaccine 2008, 26, 2930-2934. [CrossRef] [PubMed]

97. Kalthoff, D.; Globig, A.; Beer, M. Highly pathogenic avian influenza as a zoonotic agent. Vet. Microbiol. 2010, 140, 237-245. [CrossRef] [PubMed]

98. Nemchinov, L.G.; Natilla, A. Transient expression of the ectodomain of matrix protein 2 (M2e) of avian influenza A virus in plants. Protein Expr. Purif. 2007, 56, 153-159. [CrossRef] [PubMed] 
99. Muthamilselvan, T.; Lee, C.W.; Cho, Y.H.; Wu, F.C.; Hu, C.C.; Liang, Y.C.; Lin, N.S.; Hsu, Y.H. A transgenic plant cell-suspension system for expression of epitopes on chimeric Bamboo mosaic virus particles. Plant Biotechnol. J. 2016, 14, 231-239. [CrossRef] [PubMed]

100. Lim, S.; Nam, M.; Kim, K.H.; Lee, S.H.; Moon, J.K.; Lim, H.S.; Choung, M.G.; Kim, S.M.; Moon, J.S. Development of a new vector using Soybean yellow common mosaic virus for gene function study or heterologous protein expression in soybeans. J. Virol. Methods 2016, 228, 1-9. [CrossRef] [PubMed]

101. Rao, J.P.; Agrawal, P.; Mohammad, R.; Rao, S.K.; Reddy, G.R.; Dechamma, H.J.; Suryanarayana, V.V. Expression of VP1 protein of serotype A and $\mathrm{O}$ of foot-and-mouth disease virus in transgenic sunnhemp plants and its immunogenicity for guinea pigs. Acta Virol. 2012, 56, 91-99. [CrossRef] [PubMed]

102. Wang, Y.; Shen, Q.; Jiang, Y.; Song, Y.; Fang, L.; Xiao, S.; Chen, H. Immunogenicity of foot-and-mouth disease virus structural polyprotein P1 expressed in transgenic rice. J. Virol. Methods 2012, 181, 12-17. [CrossRef] [PubMed]

103. Pan, L.; Zhang, Y.; Wang, Y.; Wang, B.; Wang, W.; Fang, Y.; Jiang, S.; Lv, J.; Wang, W.; Sun, Y.; et al. Foliar extracts from transgenic tomato plants expressing the structural polyprotein, P1-2A, and protease, 3C, from foot-and-mouth disease virus elicit a protective response in guinea pigs. Vet. Immunol. Immunopathol. 2008, 121, 83-90. [CrossRef] [PubMed]

104. Yang, C.D.; Liao, J.T.; Lai, C.Y.; Jong, M.H.; Liang, C.M.; Lin, Y.L.; Lin, N.S.; Hsu, Y.H.; Liang, S.M. Induction of protective immunity in swine by recombinant bamboo mosaic virus expressing foot-and-mouth disease virus epitopes. BMC Biotechnol. 2007, 7, 62. [CrossRef] [PubMed]

105. Park, S.R.; Lim, C.Y.; Kim, D.S.; Ko, K. Optimization of ammonium sulfate concentration for purification of colorectal cancer vaccine candidate recombinant protein GA733-FcK isolated from plants. Front. Plant Sci. 2015, 6, 1040. [CrossRef] [PubMed]

106. Ahn, J.; Lee, K.J.; Ko, K. Optimization of ELISA conditions to quantify colorectal cancer antigen-antibody complex protein (GA733-FcK) expressed in transgenic plant. Monoclon. Antib. Immunodiagn. Immunother. 2014, 33, 1-7. [CrossRef] [PubMed]

107. Lu, Z.; Lee, K.-J.; Shao, Y.; Lee, J.-H.; So, Y.; Choo, Y.-K.; Oh, D.-B.; Hwang, K.-A.; Oh, S.H.; Han, Y.S.; et al. Expression of GA733-Fc fusion protein as a vaccine candidate for colorectal cancer in transgenic plants. BioMed Res. Int. 2012. [CrossRef] [PubMed]

108. Brodzik, R.; Spitsin, S.; Golovkin, M.; Bandurska, K.; Portocarrero, C.; Okulicz, M.; Steplewski, Z.; Koprowski, H. Plant-derived EpCAM antigen induces protective anti-cancer response. Cancer Immunol. Immunother. 2008, 57, 317-323. [CrossRef] [PubMed]

109. Satoh, N.; Kon, T.; Yamagishi, N.; Takahashi, T.; Natsuaki, T.; Yoshikawa, N. Apple latent spherical virus vector as vaccine for the prevention and treatment of mosaic diseases in pea, broad bean, and eustoma plants by Bean yellow mosaic virus. Viruses 2014, 6, 4242-4257. [CrossRef] [PubMed]

110. Gorantala, J.; Grover, S.; Rahi, A.; Chaudhary, P.; Rajwanshi, R.; Sarin, N.B.; Bhatnagar, R. Generation of protective immune response against anthrax by oral immunization with protective antigen plant-based vaccine. J. Biotechnol. 2014, 176, 1-10. [CrossRef] [PubMed]

111. Gorantala, J.; Grover, S.; Goel, D.; Rahi, A.; Magani, S.K.J.; Chandra, S.; Bhatnagar, R. A plant based protective antigen [PA (dIV)] vaccine expressed in chloroplasts demonstrates protective immunity in mice against anthrax. Vaccine 2011, 29, 4521-4533. [CrossRef] [PubMed]

112. Smith, C.M.; Fry, S.C.; Gough, K.C.; Patel, A.J.; Glenn, S.; Goldrick, M.; Roberts, I.S.; Whitelam, G.C.; Andrew, P.W. Recombinant plants provide a new approach to the production of bacterial polysaccharide for vaccines. PLoS ONE 2014, 9, e88144. [CrossRef] [PubMed]

113. Salazar-Gonzalez, J.A.; Rosales-Mendoza, S.; Romero-Maldonado, A.; Monreal-Escalante, E.; Uresti-Rivera, E.E.; Bañuelos-Hernández, B. Production of a plant-derived immunogenic protein targeting ApoB100 and CETP: Toward a plant-based atherosclerosis vaccine. Mol. Biotechnol. 2014, 56, 1133-1142. [CrossRef] [PubMed]

114. He, J.; Peng, L.; Lai, H.; Hurtado, J.; Stahnke, J.; Chen, Q. A plant-produced antigen elicits potent immune responses against West Nile virus in mice. BioMed Res. Int. 2014. [CrossRef] [PubMed]

115. Sherman, A.; Su, J.; Lin, S.; Wang, X.; Herzog, R.W.; Daniell, H. Suppression of inhibitor formation against FVIII in a murine model of hemophilia A by oral delivery of antigens bioencapsulated in plant cells. Blood 2014, 124, 1659-1668. [CrossRef] [PubMed] 
116. Okamura, K.; Matsuda, Y.; Igari, K. Effects of plant cultivation density and light intensity on the production of a vaccine against swine edema disease in transgenic lettuce. Environ. Control Biol. 2013, 51, 207-213. [CrossRef]

117. Matsui, T.; Takita, E.; Sato, T.; Aizawa, M.; Ki, M.; Kadoyama, Y.; Hirano, K.; Kinjo, S.; Asao, H.; Kawamoto, K.; et al. Production of double repeated B subunit of Shiga toxin 2e at high levels in transgenic lettuce plants as vaccine material for porcine edema disease. Transgenic Res. 2011, 20, 735-748. [CrossRef] [PubMed]

118. Karimi, F.; Mousavi, A.; Salmanian, A.H.; Alizadeh, H.; Rafati, S. Immunogenicity of EIT chimeric protein expressed in transplastomic tobacco plants towards development of an oral vaccine against Escherichia coli O157:H7. Plant Biotechnol. Rep. 2013, 7, 535-546. [CrossRef]

119. Yuki, Y.; Mejima, M.; Kurokawa, S.; Hiroiwa, T.; Takahashi, Y.; Tokuhara, D.; Nochi, T.; Katakai, Y.; Kuroda, M.; Takeyama, N.; et al. Induction of toxin-specific neutralizing immunity by molecularly uniform rice-based oral cholera toxin B subunit vaccine without plant-associated sugar modification. Plant Biotechnol. J. 2013, 11, 799-808. [CrossRef] [PubMed]

120. Matsumoto, Y.; Suzuki, S.; Nozoye, T.; Yamakawa, T.; Takashima, Y.; Arakawa, T.; Tsuji, N.; Takaiwa, F.; Hayashi, Y. Oral immunogenicity and protective efficacy in mice of transgenic rice plants producing a vaccine candidate antigen (As16) of Ascaris suum fused with cholera toxin B subunit. Transgenic Res. 2009, 18, 185-192. [CrossRef] [PubMed]

121. Shin, E.A.; Lee, J.Y.; Kim, T.G.; Park, Y.K.; Langridge, W.H. Synthesis and assembly of an adjuvanted Porphyromonas gingivalis fimbrial antigen fusion protein in plants. Protein Expr. Purif. 2006, 47, 99-109. [CrossRef] [PubMed]

122. Gómez, E.; Lucero, M.S.; Zoth, S.C.; Carballeda, J.M.; Gravisaco, M.J.; Berinstein, A. Transient expression of VP2 in Nicotiana benthamiana and its use as a plant-based vaccine against infectious bursal disease virus. Vaccine 2013, 31, 2623-2627. [CrossRef] [PubMed]

123. Lentz, E.; Mozgovoj, M.V.; Bellido, D.; Santos, M.D.; Wigdorovitz, A.; Bravo-Almonacid, F. VP8 antigen produced in tobacco transplastomic plants confers protection against bovine rotavirus infection in a suckling mouse model. J. Biotechnol. 2011, 156, 100-107. [CrossRef] [PubMed]

124. Mikschofsky, H.; Heilmann, E.; Schmidtke, J.; Schmidt, K.; Meyer, U.; Leinweber, P.; Broer, I. Greenhouse and field cultivations of antigen-expressing potatoes focusing on the variability in plant constituents and antigen expression. Plant Mol. Biol. 2011, 76, 131-144. [CrossRef] [PubMed]

125. Zhou, B.; Zhang, Y.; Wang, X.; Dong, J.; Wang, B.; Han, C.; Yu, J.; Li, D. Oral administration of plant-based rotavirus VP6 induces antigen-specific IgAs, IgGs and passive protection in mice. Vaccine 2010, 28, 6021-6027. [CrossRef] [PubMed]

126. Aguirreburualde, M.S.P.; Gómez, M.C.; Ostachuk, A.; Wolman, F.; Albanesi, G.; Pecora, A.; Odeon, A.; Ardila, F.; Escribano, J.M.; Santos, M.J.D. Efficacy of a BVDV subunit vaccine produced in alfalfa transgenic plants. Vet. Immunol. Immunopathol. 2013, 151, 315-324. [CrossRef] [PubMed]

127. Nelson, G.; Marconi, P.; Periolo, O.; la Torre, J.; Alvarez, M.A. Immunocompetent truncated E2 glycoprotein of bovine viral diarrhea virus (BVDV) expressed in Nicotiana tabacum plants: A candidate antigen for new generation of veterinary vaccines. Vaccine 2012, 30, 4499-4504. [CrossRef] [PubMed]

128. Pelosi, A.; Piedrafita, D.; de Guzman, G.; Shepherd, R.; Hamill, J.D.; Meeusen, E.; Walmsley, A.M. The effect of plant tissue and vaccine formulation on the oral immunogenicity of a model plant-made antigen in sheep. PLoS ONE 2012, 7, e52907. [CrossRef] [PubMed]

129. De Guzman, G.; Walmsley, A.M.; Webster, D.E.; Hamill, J.D. Use of the wound-inducible NtQPT2 promoter from Nicotiana tabacum for production of a plant-made vaccine. Biotechnol. Lett. 2012, 34, 1143-1150. [CrossRef] [PubMed]

130. Pelosi, A.; Shepherd, R.; de Guzman, G.; Hamill, J.; Meeusen, E.; Sanson, G.; Walmsley, A.M. The release and induced immune responses of a plant-made and delivered antigen in the mouse gut. Curr. Drug. Deliv. 2011, 8, 612-621. [CrossRef] [PubMed]

131. Sathish, K.; Sriraman, R.; Subramanian, B.M.; Rao, N.H.; Kasa, B.; Donikeni, J.; Narasu, M.L.; Srinivasan, V. Plant expressed coccidial antigens as potential vaccine candidates in protecting chicken against coccidiosis. Vaccine 2012, 30, 4460-4464. [CrossRef] [PubMed]

132. Hu, J.; Ni, Y.; Dryman, B.A.; Meng, X.; Zhang, C. Immunogenicity study of plant-made oral subunit vaccine against porcine reproductive and respiratory syndrome virus (PRRSV). Vaccine 2012, 30, 2068-2074. [CrossRef] [PubMed] 
133. Buyel, J.F.; Bautista, J.A.; Fischer, R.; Yusibov, V.M. Extraction, purification and characterization of the plant-produced HPV16 subunit vaccine candidate E7 GGG. J. Chromatogr. B 2012, 880, 19-26. [CrossRef] [PubMed]

134. Waheed, M.T.; Thönes, N.; Müller, M.; Hassan, S.W.; Gottschamel, J.; Lössl, E.; Kaul, H.P.; Lössl, A.G. Plastid expression of a double-pentameric vaccine candidate containing human papillomavirus-16 L1 antigen fused with LTB as adjuvant: Transplastomic plants show pleiotropic phenotypes. Plant Biotechnol. J. 2011, 9, 651-660. [CrossRef] [PubMed]

135. Massa, S.; Franconi, R.; Brandi, R.; Muller, A.; Mett, V.; Yusibov, V.; Venuti, A. Anti-cancer activity of plant-produced HPV16 E7 vaccine. Vaccine 2007, 25, 3018-3021. [CrossRef] [PubMed]

136. Bergeron-Sandoval, L.P.; Girard, A.; Ouellet, F.; Archambault, D.; Sarhan, F. Production of human rotavirus and Salmonella antigens in plants and elicitation of fljB-specific humoral responses in mice. Mol. Biotechnol. 2011, 47, 157-168. [CrossRef] [PubMed]

137. Dadmehr, M.; Korouzhdehi, B.; Rahbarizadeh, F.; Piri, I. Isolation of OmpA gene from Salmonella typhimurium and transformation into alfalfa in order to develop an edible plant based vaccine. Afr. J. Biotechnol. 2011, 10, 854-859.

138. Kalbina, I.; Engstrand, L.; Andersson, S.; Strid, Å. Expression of Helicobacter pylori TonB protein in transgenic Arabidopsis thaliana: Toward production of vaccine antigens in plants. Helicobacter 2010, 15, 430-437. [CrossRef] [PubMed]

139. Rosales-Mendoza, S.; Soria-Guerra, R.E.; Moreno-Fierros, L.; Alpuche-Solís, Á.G.; Martínez-González, L.; Korban, S.S. Expression of an immunogenic F1-V fusion protein in lettuce as a plant-based vaccine against plague. Planta 2010, 232, 409-416. [CrossRef] [PubMed]

140. Matsuda, R.; Kubota, C.; Alvarez, M.L.; Cardineau, G.A. Biopharmaceutical protein production under controlled environments: Growth, development, and vaccine productivity of transgenic tomato plants grown hydroponically in a greenhouse. HortScience 2009, 44, 1594-1599.

141. Del Prete, G.; Santi, L.; Andrianaivoarimanana, V.; Amedei, A.; Domarle, O.; D'elios, M.; Arntzen, C.; Rahalison, L.; Mason, H. Plant-derived recombinant Fl, V, and F1-V fusion antigens of Yersinia pestis activate human cells of the innate and adaptive immune system. Int. J. Immunopathol. Pharmacol. 2009, 22, 133-143. [PubMed]

142. Arlen, P.A.; Singleton, M.; Adamovicz, J.J.; Ding, Y.; Davoodi-Semiromi, A.; Daniell, H. Effective plague vaccination via oral delivery of plant cells expressing F1-V antigens in chloroplasts. Infect. Immun. 2008, 76, 3640-3650. [CrossRef] [PubMed]

143. Mett, V.; Lyons, J.; Musiychuk, K.; Chichester, J.A.; Brasil, T.; Couch, R.; Sherwood, R.; Palmer, G.A.; Streatfield, S.J.; Yusibov, V. A plant-produced plague vaccine candidate confers protection to monkeys. Vaccine 2007, 25, 3014-3017. [CrossRef] [PubMed]

144. Alvarez, M.L.; Pinyerd, H.L.; Crisantes, J.D.; Rigano, M.M.; Pinkhasov, J.; Walmsley, A.M.; Mason, H.S.; Cardineau, G.A. Plant-made subunit vaccine against pneumonic and bubonic plague is orally immunogenic in mice. Vaccine 2006, 24, 2477-2490. [CrossRef] [PubMed]

145. Floss, D.M.; Mockey, M.; Zanello, G.; Brosson, D.; Diogon, M.; Frutos, R.; Bruel, T.; Rodrigues, V.; Garzon, E.; Chevaleyre, C.; et al. Expression and immunogenicity of the mycobacterial Ag85B/ESAT-6 antigens produced in transgenic plants by elastin-like peptide fusion strategy. J. Biomed. Biotechnol. 2010. [CrossRef] [PubMed]

146. Dorokhov, Y.L.; Sheveleva, A.A.; Frolova, O.Y.; Komarova, T.V.; Zvereva, A.S.; Ivanov, P.A.; Atabekov, J.G. Superexpression of tuberculosis antigens in plant leaves. Tuberculosis 2007, 87, 218-224. [CrossRef] [PubMed]

147. Rigano, M.M.; Dreitz, S.; Kipnis, A.-P.; Izzo, A.A.; Walmsley, A.M. Oral immunogenicity of a plant-made, subunit, tuberculosis vaccine. Vaccine 2006, 24, 691-695. [CrossRef] [PubMed]

148. Van Eck, J.; Keen, P. Continued expression of plant-made vaccines following long-term cryopreservation of antigen-expressing tobacco cell cultures. In Vitro Cell. Dev. Biol. Plant 2009, 45, 750-757. [CrossRef]

149. Wu, H.; Scissum-Gunn, K.; Singh, N.K.; Giambrone, J.J. Toward the development of a plant-based vaccine against reovirus. Avian Dis. 2009, 53, 376-381. [CrossRef] [PubMed]

150. Brodzik, R.; Spitsin, S.; Pogrebnyak, N.; Bandurska, K.; Portocarrero, C.; Andryszak, K.; Koprowski, H.; Golovkin, M. Generation of plant-derived recombinant DTP subunit vaccine. Vaccine 2009, 27, 3730-3734. [CrossRef] [PubMed] 
151. Lau, J.M.; Korban, S.S. Analysis and stability of the respiratory syncytial virus antigen in a T3 generation of transgenic tomato plants. Plant Cell Tissue Organ Cult. 2009, 96, 335-342. [CrossRef]

152. Portocarrero, C.; Markley, K.; Koprowski, H.; Spitsin, S.; Golovkin, M. Immunogenic properties of plant-derived recombinant smallpox vaccine candidate pB5. Vaccine 2008, 26, 5535-5540. [CrossRef] [PubMed]

153. Li, H.Y.; Ramalingam, S.; Chye, M.L. Accumulation of recombinant sars-cov spike protein in plant cytosol and chloroplasts indicate potential for development of plant-derived oral vaccines. Exp. Biol. Med. 2006, 231, 1346-1352.

154. Tusé, D.; Ku, N.; Bendandi, M.; Becerra, C.; Collins, R., Jr.; Langford, N.; Sancho, S.I.; de Cerio, A.L.-D.; Pastor, F.; Kandzia, R.; et al. Clinical safety and immunogenicity of tumor-targeted, plant-made Id-KLH conjugate vaccines for follicular lymphoma. BioMed Res. Int. 2015. [CrossRef]

155. Medicago Inc. Medicago Technologies. Available online: http://www.medicago.com/English/ Technologies/Why-Proficia/default.aspx (accessed on 23 November 2015).

156. Rademacher, T.; Sack, M.; Arcalis, E.; Stadlmann, J.; Balzer, S.; Altmann, F.; Quendler, H.; Stiegler, G.; Kunert, R.; Fischer, R.; et al. Recombinant antibody 2G12 produced in maize endosperm efficiently neutralizes HIV-1 and contains predominantly single-GlcNAc N-glycans. Plant Biotechnol. J. 2008, 6, 189-201. [CrossRef] [PubMed]

157. Kim, T.G.; Kim, M.Y.; Huy, N.X.; Kim, S.H.; Yang, M.S. M cell-targeting ligand and consensus dengue virus envelope protein domain III fusion protein production in transgenic rice calli. Mol. Biotechnol. 2013, 54, 880-887. [CrossRef] [PubMed]

158. Kim, M.Y.; Chung, N.D.; Yang, M.S.; Kim, T.G. Expression of a cholera toxin B subunit and consensus dengue virus envelope protein domain III fusion gene in transgenic rice callus. Plant Cell Tissue Organ Cult. 2013, 112, 311-320. [CrossRef]

159. Kim, M.Y.; Reljic, R.; Kilbourne, J.; Ceballos-Olvera, I.; Yang, M.S.; Reyes-del Valle, J.; Mason, H.S. Novel vaccination approach for dengue infection based on recombinant immune complex universal platform. Vaccine 2015, 33, 1830-1838. [CrossRef] [PubMed]

160. Phoolcharoen, W.; Dye, J.M.; Kilbourne, J.; Piensook, K.; Pratt, W.D.; Arntzen, C.J.; Chen, Q.; Mason, H.S.; Kralovetz, M.M. A nonreplicating subunit vaccine protects mice against lethal Ebola virus challenge. Proc. Natl. Acad. Sci. USA 2011, 108, 20695-20700. [CrossRef] [PubMed]

161. Kalthoff, D.; Giritch, A.; Geisler, K.; Bettmann, U.; Klimyuk, V.; Hehnen, H.R.; Gleba, Y.; Beer, M. Immunization with plant expressed hemagglutinin protects chickens from lethal highly pathogenic avian influenza virus H5N1 challenge infection. J. Virol. 2010, 84, 12002-12010. [CrossRef] [PubMed]

162. Pera, F.F.; Mutepfa, D.L.; Khan, A.M.; Els, J.H.; Mbewana, S.; van Dijk, A.A.; Rybicki, E.P.; Hitzeroth, I.I. Engineering and expression of a human rotavirus candidate vaccine in Nicotiana benthamiana. Virol. J. 2015, 12, 205. [CrossRef] [PubMed]

163. Mason, H.S.; Lam, D.M.; Arntzen, C.J. Expression of hepatitis B surface antigen in transgenic plants. Proc. Natl. Acad. Sci. USA 1992, 89, 11745-11749. [CrossRef] [PubMed]

164. Shulga, N.Y.A.; Rukavtsova, E.B.; Krymsky, M.A.; Borisova, V.N.; Melnikov, V.A.; Bykov, V.A.; Buryanov, Y.I. Expression and characterization of Hepatitis B surface antigen in transgenic potato plants. Biochemistry 2004, 69, 1158-1164. [CrossRef] [PubMed]

165. Richter, L.J.; Thanavala, Y.; Arntzen, C.J.; Mason, H.S. Production of hepatitis B surface antigen in transgenic plants for oral immunization. Nat. Biotechnol. 2000, 18, 1167-1171. [PubMed]

166. Kong, Q.; Richter, L.; Yang, Y.F.; Arntzen, C.J.; Mason, H.S.; Thanavala, Y. Oral immunization with hepatitis B surface antigen expressed in transgenic plants. Proc. Natl. Acad. Sci. USA 2001, 98, 11539-11544. [CrossRef] [PubMed]

167. Joung, Y.H.; Youm, J.W.; Jeon, J.H.; Lee, B.C.; Ryu, C.J.; Hong, H.J.; Kim, H.C.; Joung, H.; Kim, H.S. Expression of the hepatitis B surface $\mathrm{S}$ and preS2 antigens in tubers of Solanum tuberosum. Plant Cell Rep. 2004, 22, 925-930. [CrossRef] [PubMed]

168. Hayden, C.A.; Egelkrout, E.M.; Moscoso, A.M.; Enrique, C.; Keener, T.K.; Jimenez-Flores, R.; Wong, J.C.; Howard, J.A. Production of highly concentrated, heat-stable hepatitis B surface antigen in maize. Plant Biotechnol. J. 2012, 10, 979-984. [CrossRef] [PubMed] 
169. Srinivas, L.; Sunil Kumar, G.B.; Ganapathi, T.R.; Revathi, C.J.; Bapat, V.A. Transient and stable expression of hepatitis B surface antigen in tomato (Lycopersicon esculentum L.). Plant Biotechnol. Rep. 2008, 2, 1-6. [CrossRef]

170. Sunil Kumar, G.B.; Ganapathi, T.R.; Revathi, C.J.; Srinivas, L.; Bapat, V.A. Expression of hepatitis B surface antigen in transgenic banana plants. Planta 2005, 222, 484-493. [CrossRef] [PubMed]

171. Lou, X.M.; Yao, Q.H.; Zhang, Z.; Peng, R.H.; Xiong, A.S.; Wang, H.K. Expression of the human hepatitis B virus large surface antigen gene in transgenic tomato plants. Clin. Vaccine Immunol. 2007, 14, 464-469. [CrossRef] [PubMed]

172. Sunil Kumar, G.B.; Srinivas, L.; Ganapathi, T.R.; Bapat, V.A. Hepatitis B surface expression in transgenic tobacco (Nicotiana tabacum) plants using four different expression cassettes. Plant Cell Tissue Organ Cult. 2006, 84, 315-323. [CrossRef]

173. Sunil Kumar, G.B.; Ganapathi, T.R.; Revathi, C.J.; Prasad, K.S.N.; Bapat, V.A. Expression of hepatitis B surface antigen in transgenic banana plants and NT-1 cell line of tobacco. BARC News Lett. 2003, 237, 85-96.

174. Smith, M.L.; Mason, H.S.; Shuler, M.L. Hepatitis B surface antigen (HBsAg) expression in plant cell culture: Kinetics of antigen accumulation in batch culture and its intracellular form. Biotechnol. Bioeng. 2002, 80, 812-822. [CrossRef] [PubMed]

175. Thanavala, Y.; Yang, Y.F.; Lyons, P.; Mason, H.S.; Arntzen, C. Immunogenicity of transgenic plant-derived hepatitis B surface antigen. Proc. Natl. Acad. Sci. USA 1995, 92, 3358-3361. [CrossRef] [PubMed]

176. Rukavtsova, E.B.; Zolova, O.E.; Buryanova, N.; Borisova, V.N.; Bykov, V.A.; Buryanov, Y.I. Analysis of transgenic tobacco plants carrying the gene for the surface antigen of the Hepatitis B virus. Russ. J. Genet. 2003, 39, 51-56. [CrossRef]

177. Fedorowicz-Strońska, O.; Kapusta, J.; Czyż, M.; Kaczmarek, M.; Pniewski, T. Immunogenicity of parenterally delivered plant-derived small and medium surface antigens of hepatitis B virus. Plant Cell Rep. 2016, 35, 1209-1212. [CrossRef] [PubMed]

178. Kostrzak, A.; Gonzalez, M.C.; Guetard, D.; Nagaraju, D.B.; Wain-Hobson, S.; Tepfer, D.; Pniewski, T.; Sala, M. Oral administration of low doses of plant-based HBsAg induced antigen-specific IgAs and IgGs in mice, without increasing levels of regulatory T cells. Vaccine 2009, 27, 4798-4807. [CrossRef] [PubMed]

179. Ruksvtsova, E.; Abramikhina, T.; Shulga, N.Y.; Bykov, V.; Bur'Yanov, Y.I. Tissue specific expression of hepatitis B virus surface antigen in transgenic plant cells and tissue culture. Russ. J. Plant Physiol. 2007, 54, 770-775. [CrossRef]

180. Guetard, D.; Greco, R.; Gonzalez, M.C.; Celli, S.; Kostrzak, A.; Langlade-Demoyen, P.; Sala, F.; Wain-Hobson, S.; Sala, M. Immunogenicity and tolerance following HIV-1/HBV plant-based oral vaccine administration. Vaccine 2008, 26, 4477-4485. [CrossRef] [PubMed]

181. Ruksvtsova, E.; Gayazova, A.; Chebotareva, E.; Buryanov, Y.I. Production of marker-free plants expressing the gene of the hepatitis B virus surface antigen. Russ. J. Genet. 2009, 45, 924-928. [CrossRef]

182. Huang, Z.; Elkin, G.; Maloney, B.J.; Buehner, N.; Arntzen, C.J.; Thanavala, Y.; Mason, H.S. Virus-like particles expression and assembly in plants: Hepatitis B and norwalk viruses. Vaccine 2005, 23, 1851-1858. [CrossRef] [PubMed]

183. Sunil Kumar, G.B.; Ganapathi, T.R.; Srinivas, L.; Revathi, C.J.; Bapat, V.A. Secretion of hepatitis B surface antigen in transformed tobacco cell suspension cultures. Biotechnol. Lett. 2005, 27, 927-932. [CrossRef] [PubMed]

184. Sojikul, P.; Buehner, N.; Mason, H.S. A plant signal peptide-hepatitis B surface antigen fusion protein with enhanced stability and immunogenicity expressed in plant cells. Proc. Natl. Acad. Sci. USA 2003, 100, 2209-2214. [CrossRef] [PubMed]

185. Dogan, B.; Mason, H.S.; Richter, L.; Hunter, J.B.; Shuler, M.L. Process options in hepatitis B surface antigen extraction from transgenic potato. Biotechnol. Prog. 2000, 16, 435-441. [CrossRef] [PubMed]

186. Rukavtsova, E.B.; Rudenko, N.V.; Puchko, E.N.; Zakharchenko, N.S.; Buryanov, Y.I. Study of the immunogenicity of hepatitis B surface antigen synthesized in transgenic potato plants with increased biosafety. J. Biotechnol. 2015, 203, 84-88. [CrossRef] [PubMed]

187. Kapusta, J.; Modelska, A.; Figlerowicz, M.; Pniewski, T.; Letellier, M.; Lisowa, O.; Yusibov, V.; Koprowski, H.; Plucienniczak, A.; Legocki, A.B. A plant-derived edible vaccine against hepatitis B virus. FASEB J. 1999, 13, 1796-1799. [PubMed] 
188. Pniewski, T.; Kapusta, J.; Bociag, P.; Wojciechowicz, J.; Kostrzak, A.; Gdula, M.; Fedorowicz-Strońska, O.; Wójcik, P.; Otta, H.; Samardakiewicz, S. Low-dose oral immunization with lyophilized tissue of herbicide-resistant lettuce expressing hepatitis B surface antigen for prototype plant-derived vaccine tablet formulation. J. Appl. Genet. 2011, 52, 125-136. [CrossRef] [PubMed]

189. Czyż, M.; Dembczynski, R.; Marecik, R.; Wojas-Turek, J.; Milczarek, M.; Pajtasz-Piasecka, E.; Wietrzyk, J.; Pniewski, T. Freeze-drying of plant tissue containing HBV surface antigen for the oral vaccine against hepatitis B. BioMed Res. Int. 2014. [CrossRef] [PubMed]

190. Ganapathi, T.R.; Sunil Kumar, G.B.; Srinivas, L.; Revathi, C.J.; Bapat, V.A. Analysis of the limitations of hepatitis B surface antigen expression in soybean cell suspension cultures. Plant Cell Rep. 2007, 26, 1575-1584. [CrossRef] [PubMed]

191. Salyaev, R.; Stolbikov, A.; Rekoslavskaya, N.; Shchelkunov, S.; Pozdnyakov, S.; Chepinoga, A.; Hammond, R. Obtaining tomato plants transgenic for the preS2-S-HDEL gene, which synthesize the major hepatitis $\mathrm{B}$ surface antigen. Dokl. Biochem. Biophys. 2010, 433, 187-190. [CrossRef] [PubMed]

192. Pniewski, T.; Kapusta, J.; Płucienniczak, A. Agrobacterium tumefaciens-mediated transformation of yellow lupin to generate callus tissue producing surface antigen of HBV in a long-term culture. J. Appl. Genet. 2006, 47, 309-318. [CrossRef] [PubMed]

193. Hayden, C.A.; Streatfield, S.J.; Lamphear, B.J.; Fake, G.M.; Keener, T.K.; Walker, J.H.; Clements, J.D.; Turner, D.D.; Tizard, I.R.; Howard, J.A. Bioencapsulation of the hepatitis B surface antigen and its use as an effective oral immunogen. Vaccine 2012, 30, 2937-2942. [CrossRef] [PubMed]

194. Hayden, C.A.; Smith, E.M.; Turner, D.D.; Keener, T.K.; Wong, J.C.; Walker, J.H.; Tizard, I.R.; Jimenez-Flores, R.; Howard, J.A. Supercritical fluid extraction provides an enhncement to the immune response for orally-delivered hepatitis B surface antigen. Vaccine 2014, 32, 1240-1246. [CrossRef] [PubMed]

195. Hayden, C.A.; Fischer, M.E.; Andrews, B.L.; Chilton, H.C.; Turner, D.D.; Walker, J.H.; Tizard, I.R.; Howard, J.A. Oral delivery of wafers made from HBsAg-expressing maize germ induces long-term immunological systemic and mucosal responses. Vaccine 2015, 33, 2881-2886. [CrossRef] [PubMed]

196. Gao, Y.; Ma, Y.; Li, M.; Cheng, T.; Li, S.-W.; Zhang, J.; Xia, N.-S. Oral immunization of animals with transgenic cherry tomatillo expressing HBsAg. World J. Gastroenterol. 2003, 9, 996-1002. [CrossRef] [PubMed]

197. Lin, B.; Jin, Z.; Li, M. Construction of a plant effective expression vector containing the gene of hepatitis B virus surface antigen. Zhong Xi Yi Jie He Xue Bao 2006, 4, 639-643. [CrossRef] [PubMed]

198. Imani, J.; Berting, A.; Nitsche, S.; Schaefer, S.; Gerlich, W.H.; Neumann, K.H. The integration of a major hepatitis B virus gene into cell-cycle synchronized carrot cell suspension cultures and its expression in regenerated carrot plants. Plant Cell Tissue Organ Cult. 2002, 71, 157-164. [CrossRef]

199. Peng, J.; Song, Q.; Chengkui, T. Expression of hepatitis B surface antigen gene (HBsAg) in Laminaria japonica (Laminariales, Phaeophyta). Chin. Sci. Bull. 2002, 47, 1438-1440.

200. Chen, H.Y.; Zhang, J.; Gao, Y.; Du, H.L.; Ma, Y.; Zheng, W.Z.; Xia, N.S. Transforming HBsAg into peanut and detection of its immunogenecity. Lett. Biotechnol. 2002, 31, 245-250.

201. Pniewski, T.; Kapusta, J.; Bociąg, P.; Kostrzak, A.; Fedorowicz-Strońska, O.; Czyż, M.; Gdula, M.; Krajewski, P.; Wolko, B.; Płucienniczak, A. Plant expression, lyophilisation and storage of HBV medium and large surface antigens for a prototype oral vaccine formulation. Plant Cell Rep. 2012, 31, 585-595. [CrossRef] [PubMed]

202. Youm, J.W.; Won, Y.S.; Jeon, J.H.; Ryu, C.J.; Choi, Y.K.; Kim, H.C.; Kim, B.D.; Joung, H.; Kim, H.S. Oral immunogenicity of potato-derived HBsAg middle protein in BALB/c mice. Vaccine 2007, 25, 577-584. [CrossRef] [PubMed]

203. Salyaev, R.; Rekoslavskaya, N.; Stolbikov, A.; Hammond, R.; Shchelkunov, S. Retention of the ability to synthesize HIV-1 and HBV antigens in generations of tomato plants transgenic for the TBI-HBS gene. Dokl. Biochem. Biophys. 2009, 425, 120-123. [CrossRef] [PubMed]

204. Salyaev, R.; Rekoslavskaya, N.; Stolbikov, A.; Hammond, R.; Shchelkunov, S. Synthesis of hepatitis B virus surface antigen in tomato plants transgenic for the preS2-S gene. Dokl. Biochem. Biophys. 2007, 416, 290-293. [CrossRef] [PubMed]

205. Salyaev, R.K.; Rekoslavskaya, N.I.; Stolbikov, A.S.; Tret'yakova, A.V. Candidate mucosal vaccine against hepatitis B based on tomatoes transgenic for the preS2-S gene. Dokl. Biochem. Biophys. 2012, 446, 257-259. [CrossRef] [PubMed] 
206. Deineko, E.; Zagorskaya, A.; Pozdnyakov, S.; Filipenko, E.; Permyakova, N.; Sidorchuk, Y.V.; Uvarova, E.; Pozdnyakova, L.; Shumny, V.; Vlasov, V.; et al. Comparative analysis of HBV M-antigen production in leaves of individual transgenic carrot plants. Dokl. Biochem. Biophys. 2009, 425, 76-79. [CrossRef] [PubMed]

207. Tsuda, S.; Yoshioka, K.; Tanaka, T.; Iwata, A.; Yoshikawa, A.; Watanabe, Y.; Okada, Y. Application of the human Hepatitis B virus core antigen from transgenic tobacco plants for serological diagnosis. Vox Sang. 1998, 74, 148-155. [CrossRef] [PubMed]

208. Huang, Z.; Santi, L.; LePore, K.; Kilbourne, J.; Arntzen, C.J.; Mason, H.S. Rapid, high-level production of hepatitis B core antigen in plant leaf and its immunogenicity in mice. Vaccine 2006, 24, 2506-2513. [CrossRef] [PubMed]

209. Sainsbury, F.; Lomonossoff, G.P. Extremely high-level and rapid transient protein production in plants without the use of viral replication. Plant Physiol. 2008, 148, 1212-1218. [CrossRef] [PubMed]

210. Huang, Z.; Chen, Q.; Hjelm, B.; Arntzen, C.; Mason, H. A DNA replicon system for rapid high-level production of virus-like particles in plants. Biotechnol. Bioeng. 2009, 103, 706-714. [CrossRef] [PubMed]

211. Peyret, H.; Gehin, A.; Thuenemann, E.C.; Blond, D.; El Turabi, A.; Beales, L.; Clarke, D.; Gilbert, R.J.; Fry, E.E.; Stuart, D.I.; et al. Tandem fusion of Hepatitis B core antigen allows assembly of virus-like particles in bacteria and plants with enhanced capacity to accommodate foreign proteins. PLoS ONE 2015, 10, e0120751. [CrossRef] [PubMed]

212. Boothe, J.; Nykiforuk, C.; Shen, Y.; Zaplachinski, S.; Szarka, S.; Kuhlman, P.; Murray, E.; Morck, D.; Moloney, M.M. Seed-based expression systems for plant molecular farming. Plant Biotechnol. J. 2010, 8, 588-606. [CrossRef] [PubMed]

213. Mechtcheriakova, I.A.; Eldarov, M.A.; Nicholson, L.; Shanks, M.; Skryabin, K.G.; Lomonossoff, G.P. The use of viral vectors to produce hepatitis B virus core particles in plants. J. Virol. Methods 2006, 131, 10-15. [CrossRef] [PubMed]

214. Pumpens, P.; Grens, E. HBV core particles as a carrier for B cell/T cell epitopes. Intervirology 2001, 44, 98-114. [CrossRef] [PubMed]

215. Bruss, V. Envelopment of the hepatitis B virus nucleocapsid. Virus Res. 2004, 106, 199-209. [CrossRef] [PubMed]

216. World Health Organization (WHO). Weekly Epidemiological Record; Hepatitis B Position Paper; WHO: Geneva, Switzerland, 2009; Volume 84, pp. 405-420.

217. World Health Organization (WHO). Hepatitis B Vaccines. Available online: http://www.who.int/ immunization/topics/WHO_position_paper_HepB.pdf (accessed on 18 January 2016).

218. Goldstein, S.T.; Fiore, A.E. Toward the global elimination of hepatitis B virus transmission. J. Pediatr. 2001, 139, 343-345. [CrossRef] [PubMed]

219. Conley, A.J.; Joensuu, J.J.; Jevnikar, A.M.; Menassa, R.; Brandle, J.E. Optimization of elastin-like polypeptide fusions for expression and purification of recombinant proteins in plants. Biotechnol. Bioeng. 2009, 103, 562-573. [CrossRef] [PubMed]

220. Kapusta, J.; Modelska, A.; Figlerowicz, M.; Pniewski, T.; Lisowa, O.; Koprowski, H.; Płucienniczak, A.; Legocki, A.B. Plant-based edible vaccine against HBV. Immunol. Lett. 2000, 73, 269.

221. Kapusta, J.; Modelska, A.; Pniewski, T.; Figlerowicz, M.; Jankowski, K.; Lisowa, O.; Plucienniczak, A.; Koprowski, H.; Legocki, A.B. Oral immunization of human with transgenic lettuce expressing hepatitis B surface antigen. Adv. Exp. Med. Biol. 2001, 495, 299-303. [PubMed]

222. Pniewski, T. The twenty-year story of a plant-based vaccine against Hepatitis B: Stagnation or promising prospects? Int. J. Mol. Sci. 2013, 14, 1978-1998. [CrossRef] [PubMed]

223. Brocke, P.; Schaefer, S.; Melber, K.; Jenzelewski, V.; Müller, F.; Dahlems, U.; Bartelsen, O.; Park, K.N.; Janowicz, Z.A.; Gellissen, G. Recombinant Hepatitis B vaccines: Disease characterization and vaccine production. In Production of Recombinant Proteins. Novel Microbial and Eukaryotic Systems; Gellissen, G., Ed.; Wiley-VCH Verlag GmbH \& Co. KGaA: Weinheim, Germany, 2005; pp. 319-359.

224. Tiwari, S.; Verma, P.C.; Singh, P.K.; Tuli, R. Plants as bioreactors for the production of vaccine antigens. Biotechnol. Adv. 2011, 27, 449-467. [CrossRef] [PubMed]

225. Shchelkunov, S.N.; Salyaev, R.K.; Pozdnyakov, S.G.; Rekoslavskaya, N.I.; Nesterov, A.E.; Ryzhova, T.S.; Sumtsova, V.M.; Pakova, N.V.; Mishutina, U.O.; Kopytina, T.V. Immunogenicity of a novel, bivalent, plant-based oral vaccine against hepatitis B and human immunodeficiency viruses. Biotechnol. Lett. 2006, 28, 959-967. [CrossRef] [PubMed] 
226. Skene, C.D.; Sutton, P. Saponin-adjuvanted particulate vaccines for clinical use. Methods 2006, 40, 53-59. [CrossRef] [PubMed]

227. Vajdy, M. Immunomodulatory properties of vitamins, flavonoids and plant oils and their potential as vaccine adjuvants and delivery systems. Expert Opin. Biol. Ther. 2011, 11, 1501-1513. [CrossRef] [PubMed]

228. Wang, Y.; Wang, W.; Li, N.; Yu, Y.; Cao, X. Activation of antigen-presenting cells by immunostimulatory plant DNA: A natural resource for potential adjuvant. Vaccine 2002, 20, 2764-2771. [CrossRef]

229. Czyż, M.; Dembczyński, R.; Marecik, R.; Pniewski, T. Stability of S-HBsAg in long-term stored lyophilised plant tissue. Biologicals 2016, 44, 69-72. [CrossRef] [PubMed]

(C) 2016 by the authors; licensee MDPI, Basel, Switzerland. This article is an open access article distributed under the terms and conditions of the Creative Commons Attribution (CC-BY) license (http:/ / creativecommons.org/licenses/by/4.0/). 